\title{
Hydroxyl radicals in the tropical troposphere over the Suriname rainforest: comparison of measurements with the box model MECCA
}

\author{
D. Kubistin ${ }^{1}$, H. Harder ${ }^{1}$, M. Martinez ${ }^{1}$, M. Rudolf ${ }^{1}$, R. Sander ${ }^{1}$, H. Bozem ${ }^{1, *}$, G. Eerdekens ${ }^{1,{ }^{* *}}$, H. Fischer ${ }^{1}$, \\ C. Gurk ${ }^{1}$, T. Klüpfel ${ }^{1}$, R. Königstedt ${ }^{1}$, U. Parchatka ${ }^{1}$, C. L. Schiller ${ }^{2, * * *}$, A. Stickler ${ }^{1,{ }^{* * *}}$, D. Taraborrelli ${ }^{1}$, \\ J. Williams ${ }^{1}$, and J. Lelieveld ${ }^{1}$ \\ ${ }^{1}$ Department of Atmospheric Chemistry, Max Planck Institute for Chemistry, Mainz, Germany \\ ${ }^{2}$ Department of Chemistry, York University, Toronto, Canada \\ * now at: Institute for Atmospheric Physics, Johannes Gutenberg University Mainz, Germany \\ *** now at: Interscience Expert Center, Louvain-la-Neuve, Belgium \\ **** now at: Environment Canada, Vancouver, Canada \\ **** now at: Oeschger Centre for Climate Change Research and Institute for Geography, \\ University of Bern, Switzerland
}

Received: 24 June 2008 - Published in Atmos. Chem. Phys. Discuss.: 12 August 2008

Revised: 4 October 2010 - Accepted: 5 October 2010 - Published: 15 October 2010

\begin{abstract}
As a major source region of the hydroxyl radical $\mathrm{OH}$, the Tropics largely control the oxidation capacity of the atmosphere on a global scale. However, emissions of hydrocarbons from the tropical rainforest that react rapidly with $\mathrm{OH}$ can potentially deplete the amount of $\mathrm{OH}$ and thereby reduce the oxidation capacity. The airborne GABRIEL field campaign in equatorial South America (Suriname) in October 2005 investigated the influence of the tropical rainforest on the $\mathrm{HO}_{\mathrm{x}}$ budget $\left(\mathrm{HO}_{\mathrm{x}}=\right.$ $\mathrm{OH}+\mathrm{HO}_{2}$ ). The first observations of $\mathrm{OH}$ and $\mathrm{HO}_{2}$ over a tropical rainforest are compared to steady state concentrations calculated with the atmospheric chemistry box model MECCA. The important precursors and sinks for $\mathrm{HO}_{\mathrm{x}}$ chemistry, measured during the campaign, are used as constraining parameters for the simulation of $\mathrm{OH}$ and $\mathrm{HO}_{2}$. Significant underestimations of $\mathrm{HO}_{\mathrm{x}}$ are found by the model over land during the afternoon, with mean ratios of observation to model of $12.2 \pm 3.5$ and $4.1 \pm 1.4$ for $\mathrm{OH}$ and $\mathrm{HO}_{2}$, respectively. The discrepancy between measurements and simulation results is correlated to the abundance of isoprene. While for low isoprene mixing ratios (above ocean or at altitudes $>3 \mathrm{~km}$ ), observation and simulation agree fairly well, for mixing ratios $>200 \mathrm{pptV}(<3 \mathrm{~km}$ over the rainforest) the model tends to underestimate the $\mathrm{HO}_{\mathrm{x}}$ observations as a function of isoprene.
\end{abstract}

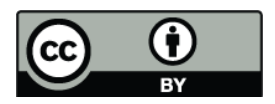

Correspondence to: D. Kubistin (dagmar.kubistin@mpic.de)
Box model simulations have been performed with the condensed chemical mechanism of MECCA and with the detailed isoprene reaction scheme of MCM, resulting in similar results for $\mathrm{HO}_{\mathrm{x}}$ concentrations. Simulations with constrained $\mathrm{HO}_{2}$ concentrations show that the conversion from $\mathrm{HO}_{2}$ to $\mathrm{OH}$ in the model is too low. However, by neglecting the isoprene chemistry in the model, observations and simulations agree much better. An $\mathrm{OH}$ source similar to the strength of the $\mathrm{OH}$ sink via isoprene chemistry is needed in the model to resolve the discrepancy. A possible explanation is that the oxidation of isoprene by $\mathrm{OH}$ not only dominates the removal of $\mathrm{OH}$ but also produces it in a similar amount. Several additional reactions which directly produce $\mathrm{OH}$ have been implemented into the box model, suggesting that upper limits in producing $\mathrm{OH}$ are still not able to reproduce the observations (improvement by factors of $\approx 2.4$ and $\approx 2$ for $\mathrm{OH}$ and $\mathrm{HO}_{2}$, respectively). We determine that $\mathrm{OH}$ has to be recycled to $94 \%$ instead of the simulated $38 \%$ to match the observations, which is most likely to happen in the isoprene degradation process, otherwise additional sources are required.

\section{Introduction}

The hydroxyl radical $(\mathrm{OH})$ and the associated hydroperoxyl radical $\left(\mathrm{HO}_{2}\right)$ play a major role in the chemistry of the troposphere, dominating its oxidation capacity during

Published by Copernicus Publications on behalf of the European Geosciences Union. 
daytime. Owing to their high chemical reactivity, $\mathrm{OH}$ and $\mathrm{HO}_{2}$ are responsible for the removal of most biogenic and anthropogenic trace gases, determining the lifetimes of gaseous pollutants and thereby directly impacting air quality (Heard et al., 2003).

The main source of $\mathrm{OH}$ in the unpolluted lower troposphere is the photolysis of ozone, followed by the reaction with water vapour (Levy, 1971):

$$
\begin{aligned}
& \mathrm{O}_{3}+h v \longrightarrow \mathrm{O}\left({ }^{1} \mathrm{D}\right)+\mathrm{O}_{2}, \quad \lambda<310 \mathrm{~nm}, \\
& \mathrm{O}\left({ }^{1} \mathrm{D}\right)+\mathrm{H}_{2} \mathrm{O} \longrightarrow 2 \mathrm{OH} .
\end{aligned}
$$

Therefore $\mathrm{OH}$ production rates are largest in tropical regions, where humidity and radiation intensity are high (Lelieveld et al., 2002).

On the other hand, emissions of biogenic trace gases are controlled by solar radiation and temperature (Kesselmeier et al., 1999; Fuentes et al., 2000). Tropical regions naturally have large areas of rainforest and these ecosystems represent a major source of volatile organic compounds (VOC) on a global scale (Fehsenfeld et al., 1992; Guenther et al., 1995). Global models typically predict a large influence from the tropical rainforest VOC emissions on the hydroxyl radical concentration (Logan et al., 1981; Karl et al., 2007) by the reaction :

$$
\mathrm{RH}+\mathrm{OH} \stackrel{\mathrm{O}_{2}}{\longrightarrow} \mathrm{RO}_{2}+\mathrm{H}_{2} \mathrm{O},
$$

which has been thought to suppress $\mathrm{OH}$ and the oxidation capacity of the atmosphere (Wang et al., 1998; Poisson et al., 2000; Lelieveld et al., 2002; Kuhlmann et al., 2004; Joeckel et al., 2006). The main biogenic volatile organic compound (BVOC) emitted from the tropical rainforest is isoprene (Guenther et al., 1995; Granier et al., 2000). Many laboratory based oxidation experiments of isoprene with $\mathrm{OH}$ have been performed (e.g., Paulson et al., 1992; Jenkin et al., 1997) and a detailed degradation scheme can be found in Jenkin et al. (1995).

The peroxy radicals generated in the initial step can further react with nitric oxide (NO), forming the hydroperoxyl radical, $\mathrm{HO}_{2}$ :

$$
\mathrm{RCH}_{2} \mathrm{O}_{2}+\mathrm{NO} \stackrel{\mathrm{O}_{2}}{\longrightarrow} \mathrm{RCHO}+\mathrm{NO}_{2}+\mathrm{HO}_{2},
$$

which can recycle $\mathrm{OH}$ via reaction with nitric oxide or ozone:

$$
\begin{aligned}
& \mathrm{HO}_{2}+\mathrm{NO} \longrightarrow \mathrm{OH}+\mathrm{NO}_{2}, \\
& \mathrm{HO}_{2}+\mathrm{O}_{3} \longrightarrow \mathrm{OH}+2 \mathrm{O}_{2} .
\end{aligned}
$$

The two radical species $\mathrm{OH}$ and $\mathrm{HO}_{2}$ can be considered to be in photochemical equilibrium on a timescale of seconds (Eisele et al., 1994).

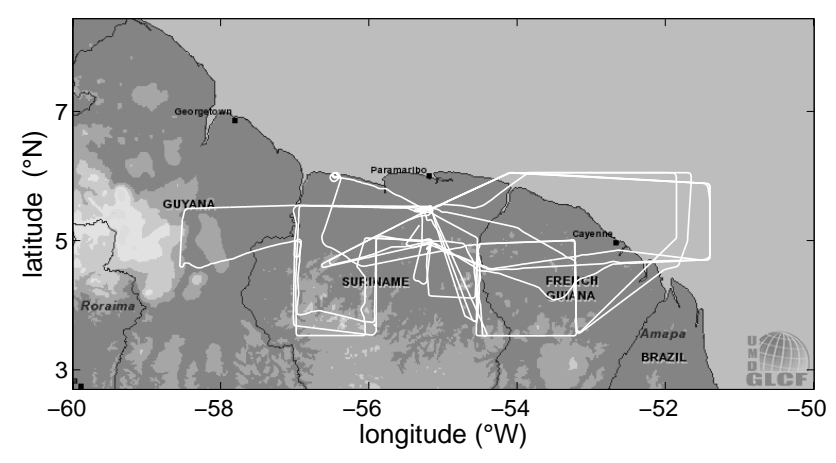

Fig. 1. Flight tracks over the Guyanas during the GABRIEL campaign (map taken from Earth Science Data Interface (ESDI), University of Maryland).

Table 1. Overview of flights performed during GABRIEL.

\begin{tabular}{lll}
\hline Flight & Date & Time of Day \\
& & \\
\hline G01 & 3 Oct 2005 & afternoon \\
G02 & 5 Oct 2005 & noon \\
G03 & 6 Oct 2005 & afternoon \\
G04 & 7 Oct 2005 & noon \\
G05 & 8 Oct 2005 & noon \\
G06 & 10 Oct 2005 & afternoon \\
G07 & 11 Oct 2005 & morning \\
G08 & 12 Oct 2005 & afternoon \\
G09 & 13 Oct 2005 & afternoon \\
G10 & 15 Oct 2005 & morning \\
\hline
\end{tabular}

The objective of the airborne GABRIEL campaign (Guyanas Atmosphere-Biosphere Exchange and Radicals Intensive Experiment with the Learjet) was to study how the VOC emissions from the pristine rainforest in equatorial South America influence the $\mathrm{HO}_{\mathrm{x}}\left(\mathrm{HO}_{\mathrm{x}}=\mathrm{OH}+\mathrm{HO}_{2}\right)$ budget. In this study, the impact of BVOCs on the $\mathrm{HO}_{\mathrm{x}}$ budget is investigated by comparing the measurements with an observationally constrained box model in steady state. The differences between model and observations for $\mathrm{HO}_{\mathrm{x}}$ are analysed and possible modifications of the chemical reaction scheme are discussed.

\section{Measurements}

The GABRIEL campaign took place over Suriname, French Guiana and Guyana $\left(3^{\circ}\right.$ to $6^{\circ} \mathrm{N}, 51^{\circ}$ to $\left.59^{\circ} \mathrm{W}\right)$. This region is sparsely populated and mainly characterised by pristine rainforest. Flights were performed from Zanderij Airport, Suriname $\left(5^{\circ} \mathrm{N}, 55^{\circ} \mathrm{W}\right)$ in October 2005 , during the long dry season (August-November). The prevailing wind direction during the campaign was from the tropical Atlantic Ocean towards the rainforest (southeasterly trade winds). The wind 

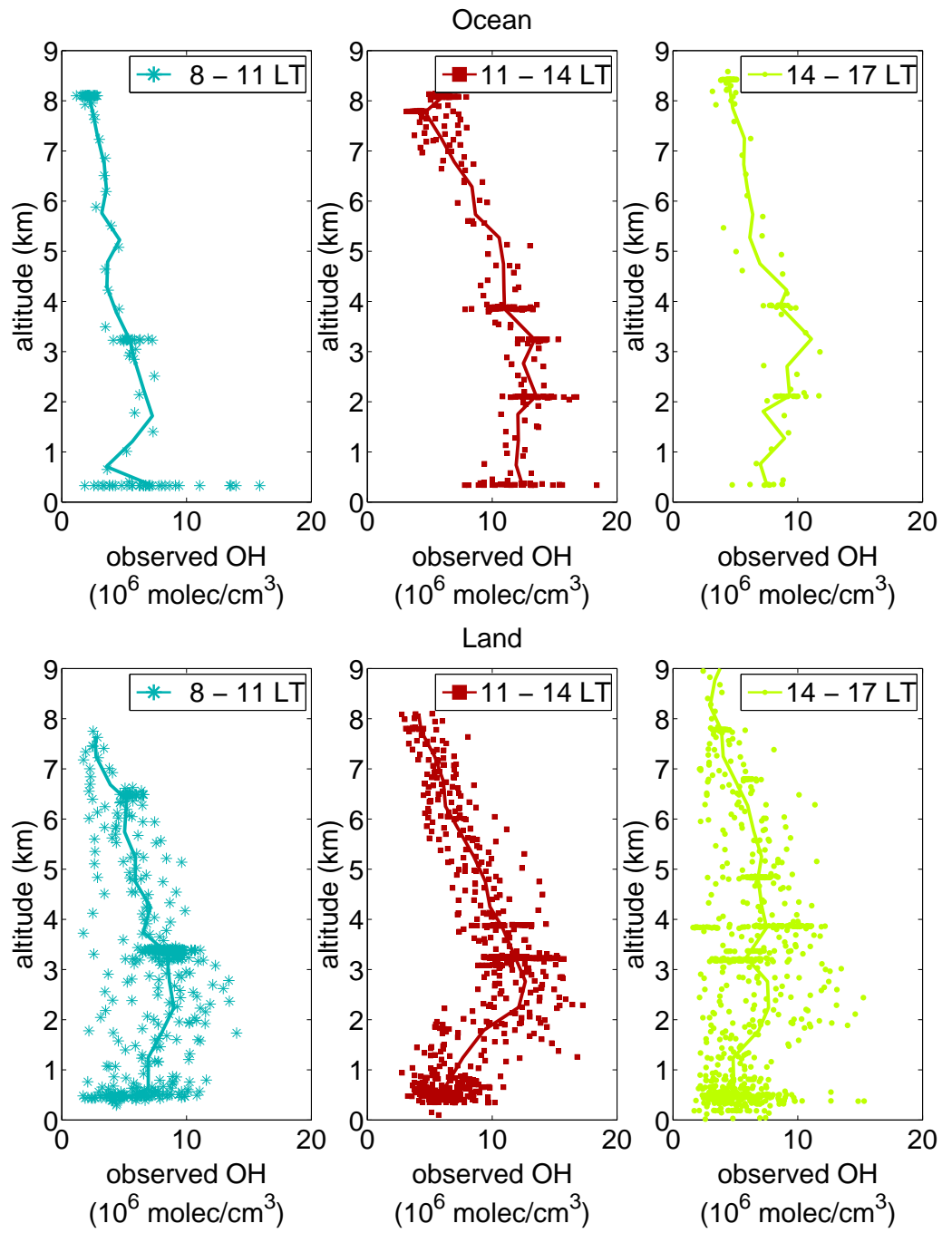

Fig. 2. OH ( $30 \mathrm{~s}$ average) observed for all flights as a function of altitude. The thick line denotes the mean values in $500 \mathrm{~m}$ bins. Upper row represents the situation over the ocean for different times of the day (left to right panel), lower row shows the situation over land.

therefore transported clean background maritime air over the forested regions of the Guyanas. Flights were performed to sample air at various altitudes $(300 \mathrm{~m}-9 \mathrm{~km})$ and at different distances from the coast (Fig. 1), hence determining the extent of biogenic influence. The flights were conducted at different times of the day (Table 1), since the primary production of $\mathrm{OH}$ in the troposphere is light dependent (R1), as are the emissions of trace gases from the rainforest (Fuentes et al., 2000).

Many important species relevant for fast photochemistry were measured in situ on board a Learjet 35A D-CGFD $\left(\mathrm{GFD}^{1}\right)$. OH was directly detected by the laser induced fluorescence (LIF) technique, whereas $\mathrm{HO}_{2}$ was quantified indirectly by conversion to $\mathrm{OH}$ via addition of $\mathrm{NO}$ (Martinez et al., 2010). These are the first reported observations of $\mathrm{HO}_{\mathrm{x}}$

\footnotetext{
${ }^{1}$ Gesellschaft für Flugzieldarstellung, Hohn, Germany
}

over the tropical rainforest (Lelieveld et al., 2008). The time resolution of the measurements varied from one to $30 \mathrm{~s}$. An overview of the measured species is given in Table 2.

The measured $\mathrm{HO}_{\mathrm{x}}$ data is shown in Figs. 2 and 3. The data (30 s average) was binned in 3-h time intervals to distinguish between morning, noon and afternoon conditions. Local time is UTC (Universal Time Coordinated) minus $3 \mathrm{~h}$. The $1 \sigma$ uncertainty of the $\mathrm{OH}$ and $\mathrm{HO}_{2}$ measurements was estimated to be $20 \%$ and $30 \%$ by the systematic error and $7 \%$ and $1 \%$ by the statistical error (as mean value), respectively. A more detailed description can be found in Martinez et al. (2010).

The influence of the rainforest emissions in the boundary layer $(<1000 \mathrm{~m})$ is illustrated by the decrease in the $\mathrm{OH}$ concentration in the airmass travelling from the ocean to the land. As the VOC accumulate in the atmosphere over the rainforest, they reduce $\mathrm{OH}$ and contribute to $\mathrm{HO}_{2}$ production. 

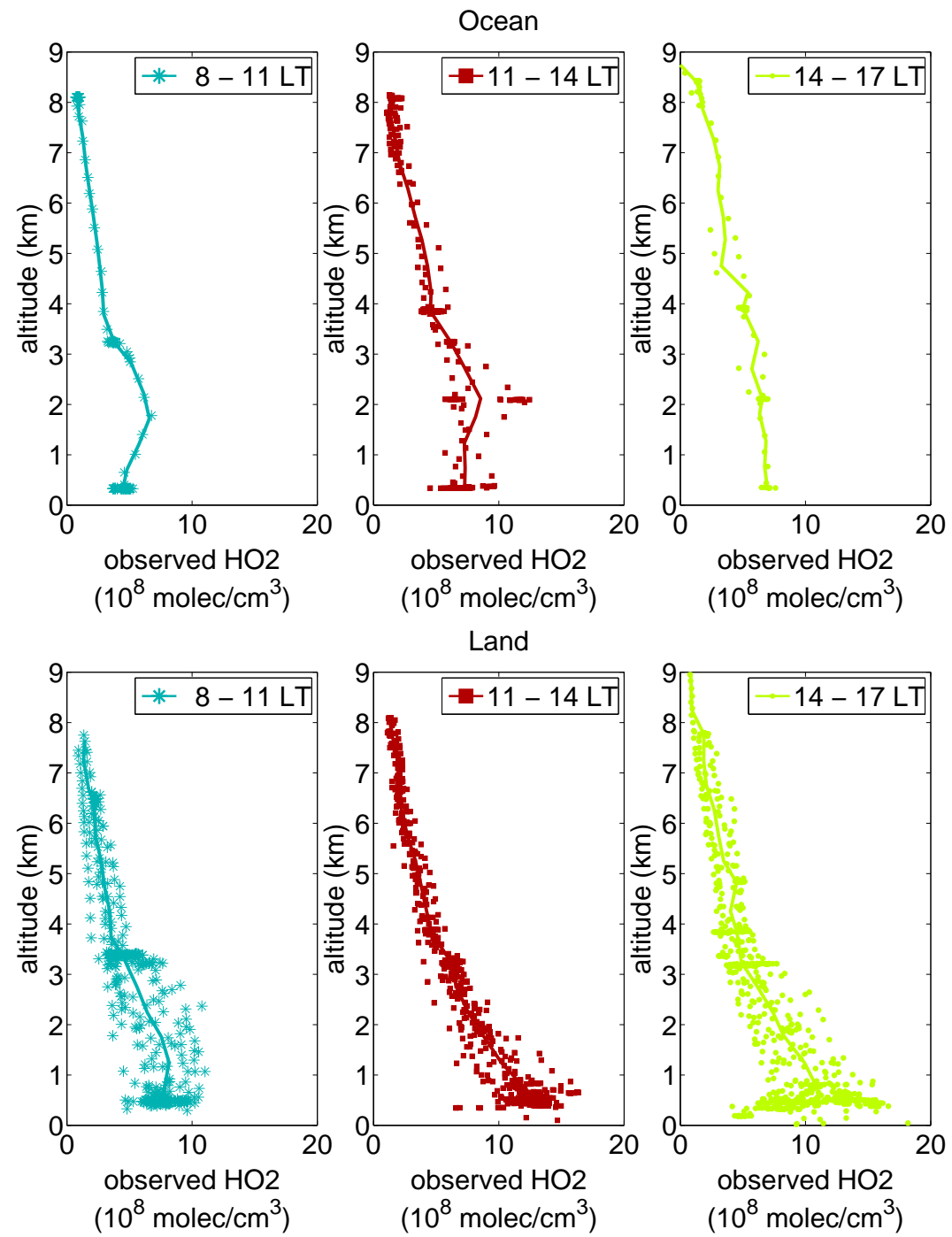

Fig. 3. $\mathrm{HO}_{2}(30 \mathrm{~s}$ average) observed for all flights as a function of altitude. The thick line denotes the mean values in $500 \mathrm{~m}$ bins. Upper row represents the situation over the ocean for different times of the day (left to right panel), lower row shows the situation over land.

To quantify our understanding of the tropospheric chemical processes in more detail, comparisons with box model calculations have been performed. It will be shown that, although $\mathrm{OH}$ concentrations decreased over the rainforest, this decrease was much less than expected and possible explanations will be discussed.

\section{Box model}

The comparison of observed data with chemical box model calculations helps to improve our understanding of the atmospheric oxidation mechanisms. For our analysis, the photochemical box model MECCA (Module Efficiently $C$ alculating the Chemistry of the Atmosphere) was used to simulate $\mathrm{OH}$ and $\mathrm{HO}_{2}$. The chemical reaction scheme is based on MECCA v0.1p (Sander et al., 2005) containing the "Mainz Isoprene Mechanism" (MIM) (Poeschl et al., 2000 ) with 44 reactions and 16 organic species describing the chemistry of isoprene. The maximum number of species in the gas phase is 116 with a total number of 295 reactions. For the simulations, the halogen, sulfur and aqueous phase reactions were neglected and the multiphase chemistry, represented as heterogeneous loss, was only considered in order to represent the deposition of peroxides. The detailed reaction scheme can be found in the accompanying Supplement.

MIM is a reduced reaction scheme in which different species belonging to a class (e.g. carbonyls, peroxy radicals, peroxides and organic nitrates) are lumped into groups of VOC. To verify the influence of the most abundant non methane hydrocarbons (NMHC) over the tropical rainforest, the comprehensive isoprene degradation scheme of the 
Table 2. Overview of the species observed and measurement techniques used during the GABRIEL campaign.

\begin{tabular}{|c|c|c|}
\hline Species & Technique & not measured for flight \\
\hline $\mathrm{OH}^{\mathrm{a}}$ & laser induced fluorescence & G01 \\
\hline $\mathrm{HO}_{2}{ }^{\mathrm{a}}$ & laser induced fluorescence & G01 \\
\hline $\mathrm{J}\left(\mathrm{NO}_{2}\right)$ & filter radiometry & \\
\hline NO & chemiluminescence & G01, G05, G10 \\
\hline $\mathrm{O}_{3}$ & chemiluminescence & G01 \\
\hline $\mathrm{HCHO}$ & quantum cascade laser absorption spectroscopy & G02 \\
\hline $\mathrm{CO}$ & quantum cascade laser absorption spectroscopy & G02 \\
\hline $\mathrm{ROOH}^{\mathrm{b}, \mathrm{c}}$ & derivatisation and fluorimetry & G01, (G05, G07) \\
\hline $\mathrm{H}_{2} \mathrm{O}_{2}{ }^{\mathrm{c}}$ & derivatisation and fluorimetry & G01, G05, G07 \\
\hline Isoprene $^{\mathrm{d}}$ & proton transfer reaction mass spectrometry & G01, G05 \\
\hline $\mathrm{MVK}+\mathrm{MACR}^{\mathrm{e}, \mathrm{d}}$ & proton transfer reaction mass spectrometry & G01, G05 \\
\hline Acetone $^{\mathrm{d}}$ & proton transfer reaction mass spectrometry & G01, G05 \\
\hline Methanol $^{\mathrm{d}}$ & proton transfer reaction mass spectrometry & G01, G05 \\
\hline $\mathrm{H}_{2} \mathrm{O}$ & infrared absorption spectrometry (LI-COR) & G02, G07 \\
\hline
\end{tabular}

${ }^{a}$ Martinez et al. (2010), ${ }^{b}$ sum of organic peroxides, ${ }^{c}$ Stickler et al. (2007), ${ }^{d}$ Eerdekens et al. (2008), ${ }^{\mathrm{e}}$ sum of methylvinylketone and methacrolein

Table 3. Mixing ratios of species which were not measured during the GABRIEL campaign and were fixed for simulation $\left(\mathrm{ppmV}=10^{-6} \cdot \frac{\mathrm{mol}}{\mathrm{mol}}, \mathrm{ppbV}=10^{-9} \cdot \frac{\mathrm{mol}}{\mathrm{mol}}, \mathrm{pptV}=10^{-12} \cdot \frac{\mathrm{mol}}{\mathrm{mol}}\right)$. Mixing ratios of alkanes and alkenes were set to zero for altitudes $>2 \mathrm{~km}$, except for $\mathrm{CH}_{4}$. Table taken from Stickler et al. (2007).

\begin{tabular}{lll}
\hline Species & $\begin{array}{l}\text { Mixing ratio } \\
\leq 2 \mathrm{~km} />2 \mathrm{~km}\end{array}$ & Reference \\
\hline $\mathrm{C}_{2} \mathrm{H}_{4}$ & $(650 / 0) \mathrm{pptV}$ & GTE ABLE 2A, Manaus, Brazil (Zimmermann et al., 1988) \\
$\mathrm{C}_{2} \mathrm{H}_{6}$ & $(794 / 0) \mathrm{pptV}$ & LBA-CLAIRE98 campaign, IMAU (Univ. Utrecht, The Netherlands) \\
$\mathrm{C}_{3} \mathrm{H}_{6}$ & $(83 / 0) \mathrm{pptV}$ & LBA-CLAIRE98 campaign, IMAU (Univ. Utrecht, The Netherlands) \\
$\mathrm{C}_{3} \mathrm{H}_{8}$ & $(83 / 0) \mathrm{pptV}$ & LBA-CLAIRE98 campaign, IMAU (Univ. Utrecht, The Netherlands) \\
$\mathrm{C}_{4} \mathrm{H}_{10}$ & $(28 / 0) \mathrm{pptV}$ & LBA-CLAIRE98 campaign, IMAU (Univ. Utrecht, The Netherlands) \\
$\mathrm{CH}_{4}$ & $1.7 \mathrm{ppmV}$ & NOAA CMDL Global Trends, ESRL Global Monitoring Division \\
$\mathrm{CO}_{2}$ & $377 \mathrm{ppmV}$ & NOAA CMDL Global Trends, ESRL Global Monitoring Division \\
$\mathrm{H}_{2}$ & $563 \mathrm{ppbV}$ & Schmidt (1974, 1978) \\
$\mathrm{HNO}_{3}$ & 0 & \\
\hline
\end{tabular}

Master Chemical Mechanism MCM 3.1 (Jenkin et al., 1997; Saunders et al., 1997, 2003) was also used in our studies.

The photolysis frequencies (J) were calculated using the radiative transfer model TUV v4.1 (Tropospheric $U$ ltraviolet-Visible Model) (Madronich et al., 1998). The ozone column was determined for every flight from satellite data (GOME, available at: www.knmi.nl) and varied around $265 \mathrm{DU}$ for all flights. The cross sections and quantum yields for the different species were taken from the recommended data of Atkinson et al. $(2004,2005)$ and Sander et al. (2006). The calculated photolysis frequencies were corrected for cloud and aerosol effects by scaling to the measured $\mathrm{J}\left(\mathrm{NO}_{2}\right)$.

Considering the short lifetimes of $\mathrm{OH}$ and $\mathrm{HO}_{2}$ radicals, all model runs were performed to reach steady state. To constrain the model runs, the measured species during the
GABRIEL campaign were fixed to their observed values with a time resolution of $2 \mathrm{~min}$. Trace gases which were not measured were either calculated by the model or taken as fixed parameters as given in Table 3. Although the instruments generally operated steadily and reliably during the GABRIEL campaign, some short interruptions, calibrations or malfunctions did occur. As nitric oxide (NO) is a crucial parameter for the $\mathrm{HO}_{\mathrm{x}}$ cycling, datasets without NO data were omitted from this study (flights G01, G05 and G10). For water vapour and carbon monoxide, missing data points were interpolated within $2 \mathrm{~min}$ intervals for equal altitude levels. For two flights (G02, G07) water data were not available. As $\mathrm{H}_{2} \mathrm{O}$ concentration correlates with altitude and the day-to-day variability was small, the mean vertical profile of water from the 8 other flights was used as a proxy to 


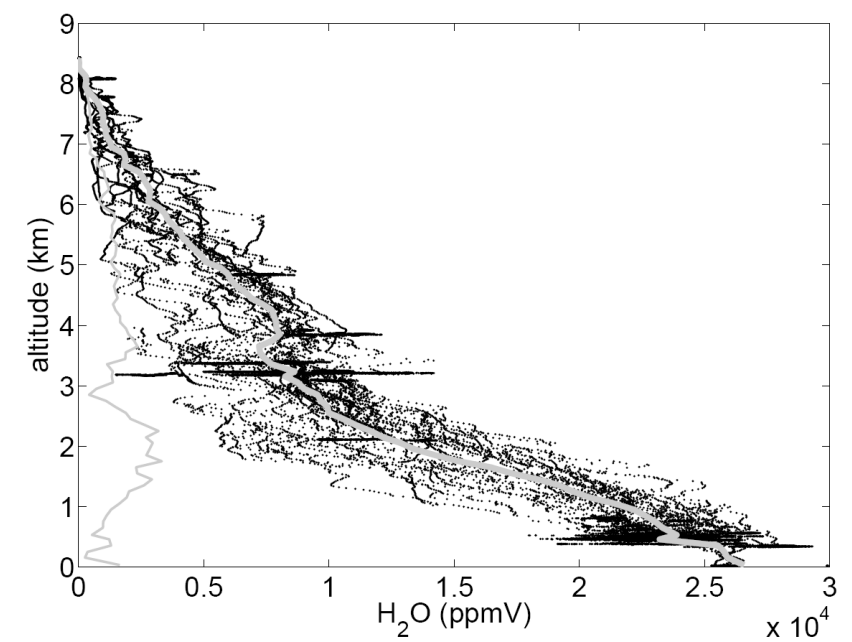

Fig. 4. Observed $\mathrm{H}_{2} \mathrm{O}$ (1 s resolution) data for all flights as a function of altitude. The thick grey line denotes the mean values for $100 \mathrm{~m}$ bins, the thin grey line the standard deviation.

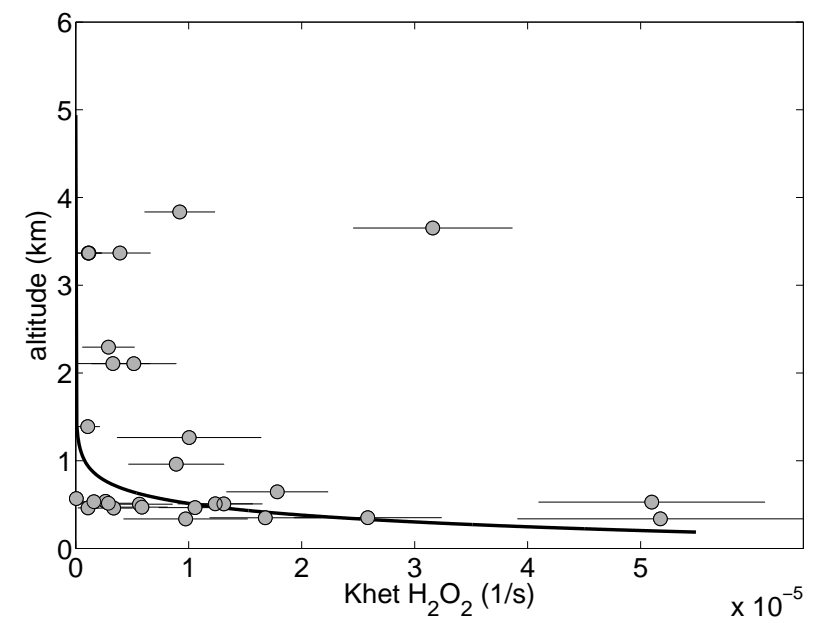

Fig. 5. Calculated heterogeneous removal rate $\operatorname{khet}\left(\mathrm{H}_{2} \mathrm{O}_{2}\right)$ as a function of altitude, as caused by wet and dry deposition processes.

fill in the missing data. The uncertainty was derived from the standard deviation of the mean profile (Fig. 4). For hydrogen peroxide $\left(\mathrm{H}_{2} \mathrm{O}_{2}\right)$, missing data were simulated by using an altitude dependent heterogeneous removal rate function, which was fitted to loss rates determined by the model to match the measured data where available (Fig. 5). This loss rate is in reasonably good agreement with calculated deposition rates by Stickler et al. (2007), who determined deposition rates in the boundary layer of $1.35 \times 10^{-5} \mathrm{~s}^{-1}$ up to $1.35 \times 10^{-4} \mathrm{~s}^{-1}$ for the tropical rainforest and about $3.25 \times 10^{-5} \mathrm{~s}^{-1}$ for the tropical Atlantic. Total organic peroxides $(\Sigma \mathrm{ROOH})$ were modelled by using the same removal rates as for $\mathrm{H}_{2} \mathrm{O}_{2}$. Comparison of the simulated and measured data shows a slight underestimation of hydrogen
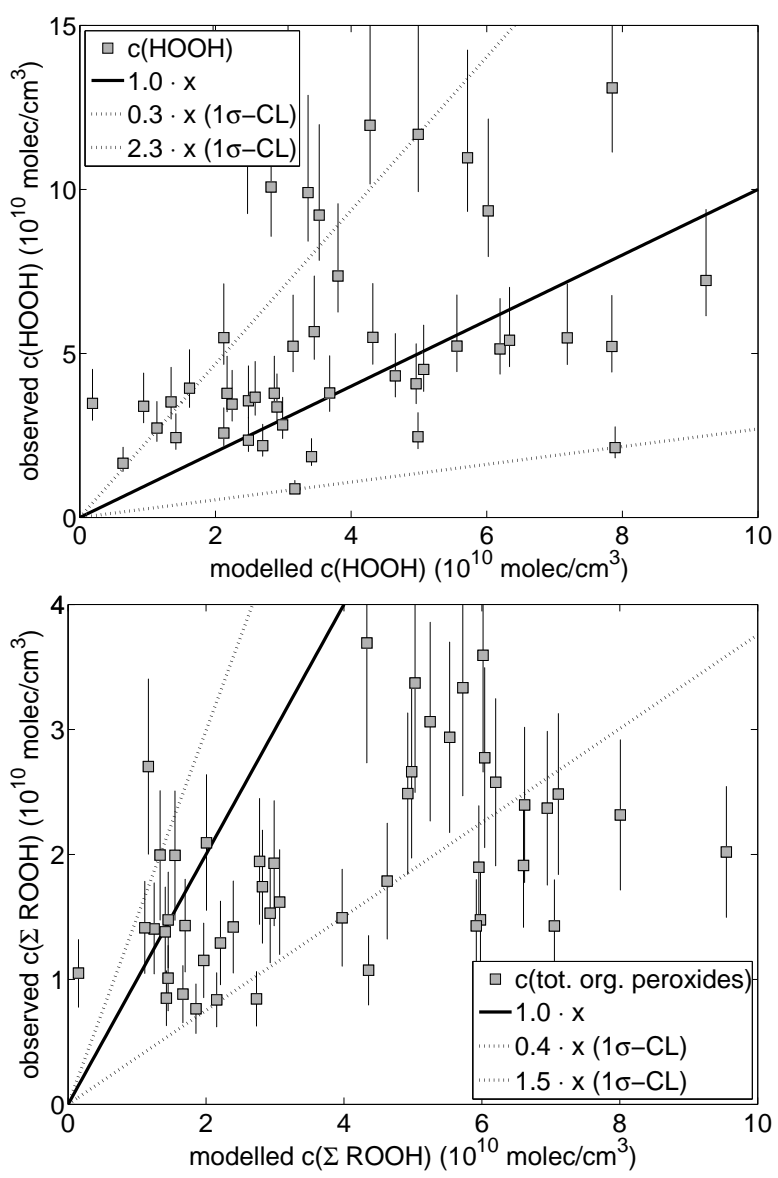

Fig. 6. Observed and modelled data for hydrogen peroxide $\left(\mathrm{H}_{2} \mathrm{O}_{2}=\mathrm{HOOH}\right)$ and total organic peroxides $(\Sigma \mathrm{ROOH})$. The solid line represent perfect agreement, the dashed lines bound the $1 \sigma$ confidence level $(1 \sigma-\mathrm{CL})$.

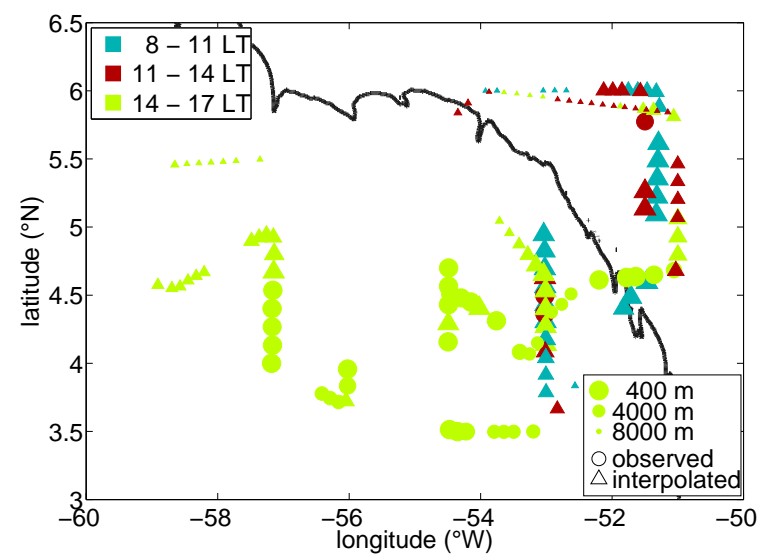

Fig. 7. Measurement locations of data points used to model $\mathrm{OH}$ and $\mathrm{HO}_{2}$. The black line represents the coastline. 

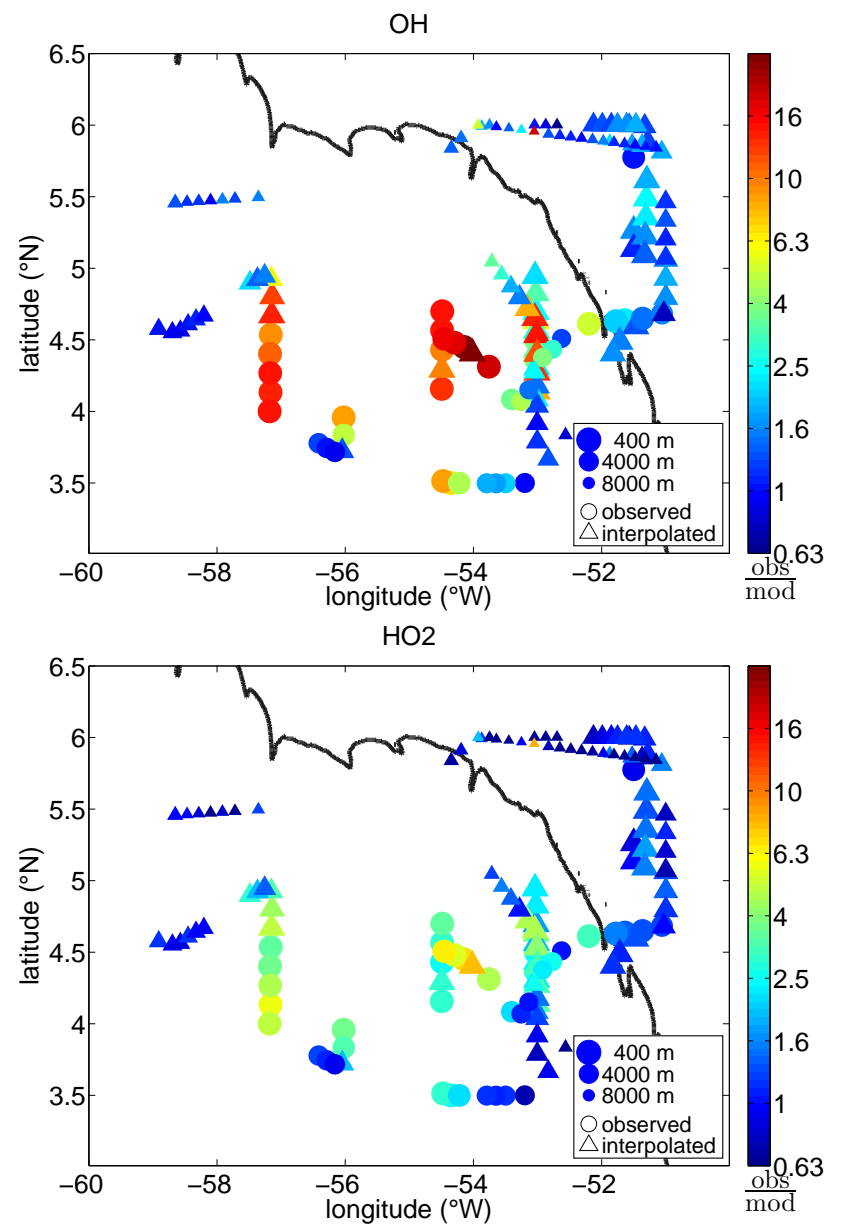

Fig. 8. Ratio of observed to simulated $\mathrm{OH}$ and $\mathrm{HO}_{2}$. The black line represents the coastline.

peroxide and overestimation of total organic peroxides (Fig. 6). For altitudes higher than $5.5 \mathrm{~km}$, measurements of total peroxides and $\mathrm{H}_{2} \mathrm{O}_{2}$ could not be carried out (Stickler et al., 2007). These missing data were simulated with a removal rate of zero (Jackson and Hewitt, 1999). Altogether, the whole dataset used for the simulation of $\mathrm{OH}$ and $\mathrm{HO}_{2}$ consists of 140 data points, corresponding to $280 \mathrm{~min}$ of data. The dataset from the direct measurements predominately comprises regions over land in the afternoon at low altitudes (Fig. 7). Datasets for the morning and for high altitudes could only be established based on the assumptions described above and accordingly have a larger uncertainty. Model simulations which used these more uncertain data points are marked separately (triangles). Nevertheless, the overall uncertainty for the modelling of $\mathrm{HO}_{\mathrm{x}}$ as caused by these assumptions is less than $50 \%$.

Uncertainties originating from the inaccuracies of the kinetic rate coefficients were estimated by Monte Carlo simulations. Hereby all kinetic rate coefficients were assumed to have an uncertainty of $15 \%$. An uncertainty of
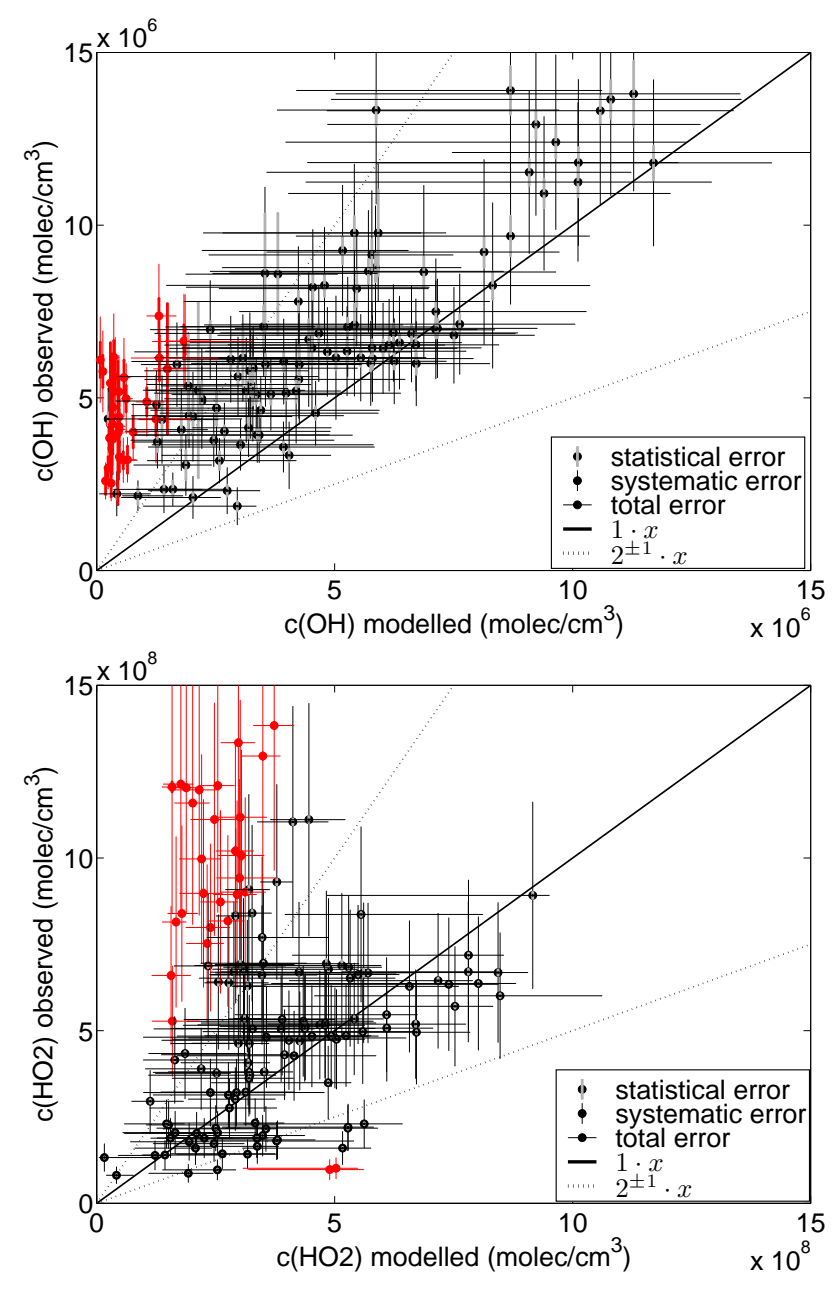

Fig. 9. Error estimates for the simulations due to measurement uncertainties. The solid line represents the perfect match of simulation and observations. The dashed lines correspond to ratios of $1: 2$ and $2: 1$. Red points illustrate deviations by more than a factor of $2^{ \pm 1}$.

$\approx 15 \%$ for the $\mathrm{OH}$ concentrations and $\approx 10 \%$ for the $\mathrm{HO}_{2}$ concentrations were obtained. The largest impact on the $\mathrm{OH}$ concentrations, depending on the different measurement situations, had the following reactions: $\mathrm{H}_{2} \mathrm{O}+\mathrm{O}\left({ }^{1} \mathrm{D}\right) \rightarrow$ $2 \mathrm{OH}(\approx 9 \%), \quad \mathrm{N}_{2}+\mathrm{O}\left({ }^{1} \mathrm{D}\right) \rightarrow \mathrm{O}\left({ }^{3} \mathrm{P}\right)+\mathrm{N}_{2}(\approx 6 \%)$, and $\mathrm{ISOP}+\mathrm{OH} \rightarrow \mathrm{ISO}_{2}(\approx 10 \%)$. Their uncertainties are given to be $<20 \%$ (Sander et al., 2003). For the $\mathrm{HO}_{2}$ radical the reaction of $\mathrm{HO}_{2}+\mathrm{HO}_{2} \rightarrow \mathrm{H}_{2} \mathrm{O}_{2}$ and $\mathrm{ISO}_{2}+\mathrm{HO}_{2} \rightarrow \mathrm{ISOOH}$ influenced the simulated $\mathrm{HO}_{2}$ concentration of about $6 \%$ and $8 \%$, respectively.

\section{Results and discussion}

To examine the radical chemistry over the tropical rainforest, diverse tropospheric conditions (e.g. time of day, altitude, background air) were covered by the flight tracks performed 
Table 4. Sensitivity studies with MECCA concerning the constrained measured species. Concentrations are mean values for the forest boundary layer $(<1 \mathrm{~km})$ in the afternoon $(14-17 \mathrm{LT})$.

\begin{tabular}{lcccccc}
\hline & $\begin{array}{c}\mathrm{OH} \\
\left(\mathrm{molec} / \mathrm{cm}^{3}\right)\end{array}$ & $1 \sigma(\%)$ & $\begin{array}{c}\mathrm{OH} \\
\text { obs/mod }\end{array}$ & $\begin{array}{c}\mathrm{HO}_{2} \\
\left(\mathrm{molec} / \mathrm{cm}^{3}\right)\end{array}$ & $1 \sigma(\%)$ & $\begin{array}{c}\mathrm{HO}_{2} \\
\text { obs/mod }\end{array}$ \\
\hline Observation & $43.9 \times 10^{5}$ & 21 & 1.0 & $10.2 \times 10^{8}$ & 19 & 1.0 \\
Reference Run & $3.84 \times 10^{5}$ & 32 & $12.2 \pm 3.5$ & $2.63 \times 10^{8}$ & 24 & $4.1 \pm 1.4$ \\
0.5 Isoprene & $5.75 \times 10^{5}$ & 31 & $8.1 \pm 2.2$ & $2.78 \times 10^{8}$ & 24 & $3.9 \pm 1.3$ \\
0.5 (MACR + MVK) & $3.98 \times 10^{5}$ & 31 & $11.8 \pm 3.4$ & $2.64 \times 10^{8}$ & 23 & $4.1 \pm 1.4$ \\
$2 \mathrm{O}_{3}$ & $6.24 \times 10^{5}$ & 33 & $7.5 \pm 2.1$ & $2.79 \times 10^{8}$ & 24 & $3.9 \pm 1.4$ \\
$2 \mathrm{NO}$ & $4.42 \times 10^{5}$ & 32 & $10.7 \pm 3.4$ & $2.90 \times 10^{8}$ & 23 & $3.7 \pm 1.3$ \\
$2 \mathrm{H} \mathrm{H}_{2} \mathrm{O}$ & $5.55 \times 10^{5}$ & 33 & $8.4 \pm 2.3$ & $2.53 \times 10^{8}$ & 24 & $4.3 \pm 1.5$ \\
$0.5 \mathrm{CO}$ & $3.84 \times 10^{5}$ & 33 & $12.2 \pm 3.5$ & $2.58 \times 10^{8}$ & 24 & $4.2 \pm 1.4$ \\
$3 \mathrm{H}_{2} \mathrm{O}_{2}$ & $4.60 \times 10^{5}$ & 37 & $10.5 \pm 3.2$ & $2.73 \times 10^{8}$ & 25 & $4.0 \pm 1.4$ \\
$2 \mathrm{HCHO}$ & $3.96 \times 10^{5}$ & 30 & $11.8 \pm 3.5$ & $3.57 \times 10^{8}$ & 25 & $3.1 \pm 1.1$ \\
$0 \mathrm{Alkanes}$ & $3.92 \times 10^{5}$ & 32 & $11.9 \pm 3.4$ & $2.63 \times 10^{8}$ & 23 & $4.1 \pm 1.4$ \\
$0.3 \mathrm{ROOH}$ & $3.74 \times 10^{5}$ & 32 & $12.6 \pm 3.6$ & $2.60 \times 10^{8}$ & 23 & $4.2 \pm 1.4$ \\
$2 \mathrm{~J}\left(\mathrm{O}^{1} \mathrm{D}\right)$ & $6.24 \times 10^{5}$ & 33 & $7.5 \pm 2.1$ & $2.76 \times 10^{8}$ & 25 & $4.0 \pm 1.5$ \\
\hline
\end{tabular}

during GABRIEL. Air influenced by rainforest emissions as well as unaffected air over the ocean was sampled. Figure 8 shows the observed to modelled ratio for $\mathrm{OH}$ and $\mathrm{HO}_{2}$ as a function of location. Over the ocean and at higher altitudes the agreement is fairly good for $\mathrm{OH}$ and $\mathrm{HO}_{2}$ with a possible slight model underestimation of $\mathrm{OH}$ and an overestimation of $\mathrm{HO}_{2}$. However over the rainforest at low altitudes, where the emission of hydrocarbons influences the chemistry, the divergence between model and observation increases strongly. These discrepancies are greater for the hydroxyl radical (up to factors of 15) than for $\mathrm{HO}_{2}$ (up to factors of 5). The substantial underestimation of the simulation is an indication of the inadequacy of the hydrocarbon chemistry scheme adopted in the model.

The uncertainty estimation for observations and simulations are included in the analyses to define the significance of the discrepancies. Figure 9 shows the $1 \sigma$ range of the observed and modelled data, derived from the measurement uncertainties of the species that constrain the model. Upper and lower estimates are obtained by varying all concentrations within the uncertainties to achieve maximum and minimum production of $\mathrm{OH}$ and $\mathrm{HO}_{2}$, and conversion of $\mathrm{HO}_{2}$ to $\mathrm{OH}$. Although $\mathrm{OH}$ and $\mathrm{HO}_{2}$ concentrations were often reproduced by the model within a factor 2, there was significant disagreement for several data points for which the simulated values were lower than the observations.

Further sensitivity studies of the model have been performed including the constraining parameters to identify the observed trace gases with the strongest influence on the $\mathrm{HO}_{\mathrm{x}}$ concentrations by varying the concentrations of the single observed species separately by factors ranging from 0 to 3. Their influence on the $\mathrm{HO}_{\mathrm{x}}$ concentration is shown for afternoon data over the rainforest in Table 4. The strongest sensitivities with respect to $\mathrm{OH}$ result from ozone photo dissociation and subsequent reaction with water vapour (163\% and $145 \%$, respectively), responsible for the primary production, and from isoprene $(150 \%)$. The simulations of $\mathrm{HO}_{2}$ are less sensitive to the applied variations, with the largest influence from formaldehyde (136\%). Thus, the variation of any single constrained parameter by a factor of 2 is not sufficient to eliminate the discrepancy between the simulated and observed $\mathrm{OH}$ and $\mathrm{HO}_{2}$ concentrations.

The role of formaldehyde was also investigated by simulating the $\mathrm{HO}_{\mathrm{x}}$ concentration simultaneously with HCHO. The unconstrained HCHO-simulations led to $1 \%$ more $\mathrm{OH}$ and $4 \%$ more $\mathrm{HO}_{2}$ in average for the boundary layer over the rainforest in the afternoon, compared to the basic run. Therefore no significant effect in relation with the $\mathrm{HCHO}$ concentrations could be distinguished.

Additional uncertainties in the $\mathrm{OH}$ and $\mathrm{HO}_{2}$ measurements due to possible interferences inside the instrument had been investigated during the intercomparison campaign $\mathrm{HO}_{\mathrm{x}} \mathrm{COMP}$ in summer 2005 . Under various tropospheric conditions, all instruments, including different measurement techniques, showed high linear correlation coefficients for daytime $\mathrm{OH}$ and $\mathrm{HO}_{2}$ concentrations (Schlosser et al., 2009; Fuchs et al., 2010). For photolysis frequencies $\mathrm{J}\left(\mathrm{O}^{1} \mathrm{D}\right)>5 \times 10^{-8} \mathrm{~s}^{-1}$ no interference due to $\mathrm{O}_{3}, \mathrm{NO}_{\mathrm{x}}, \mathrm{RO}_{\mathrm{x}}$, VOCs could be detected for the $\mathrm{OH}$ and $\mathrm{HO}_{2}$ measurements. Small dependencies on the $\mathrm{H}_{2} \mathrm{O}$ concentration were found for the $\mathrm{HO}_{2}$ observations, being only relevant for small water mixing ratios $(<0.6 \%)$. The high correlation with the absolute measurement technique DOAS gives confidence in the performance of our LIF instrument, especially for the conditions during 

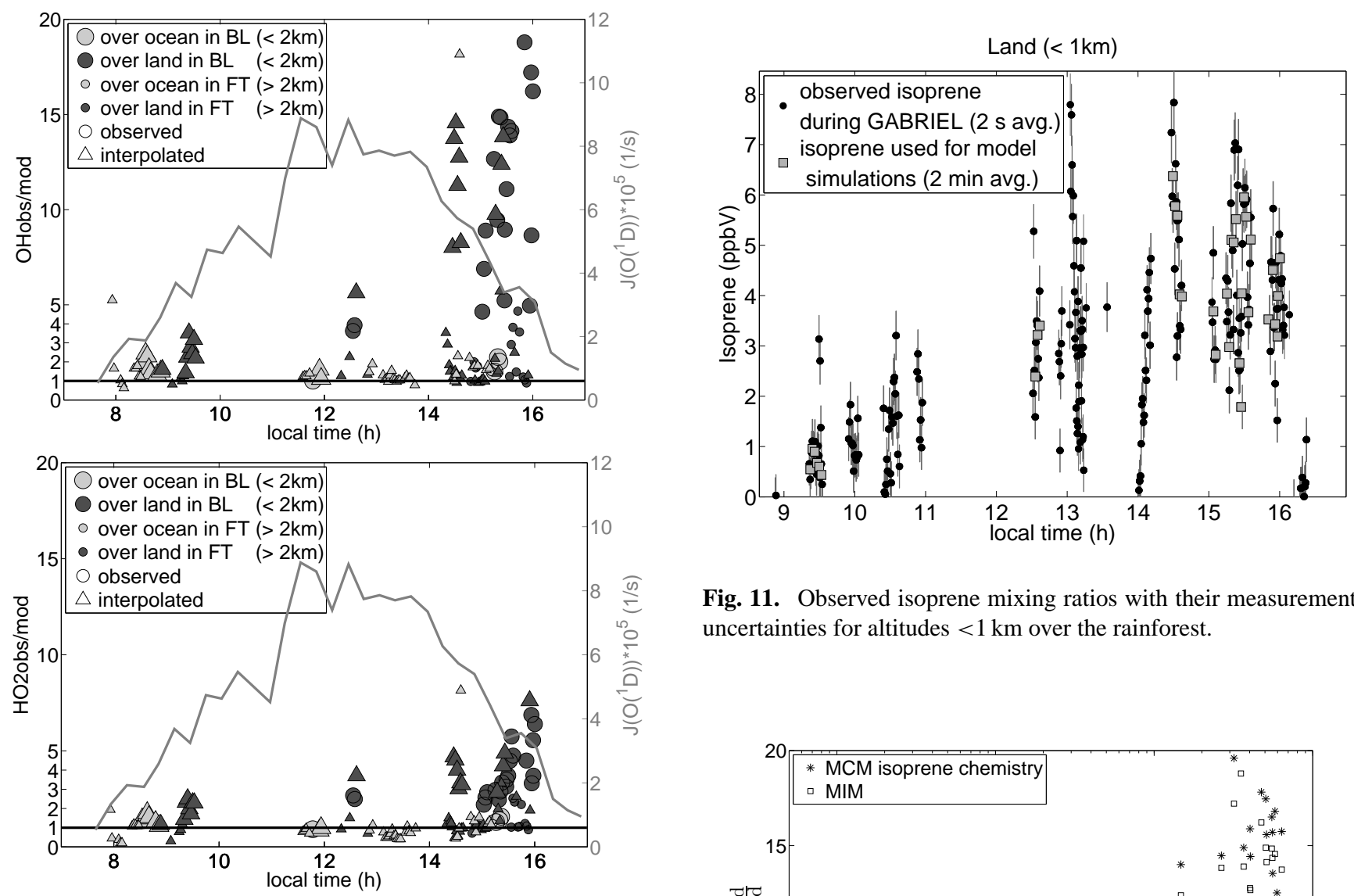

Fig. 11. Observed isoprene mixing ratios with their measurement uncertainties for altitudes $<1 \mathrm{~km}$ over the rainforest.

Fig. 10. Comparison of measurements and model results as a function of time, divided into two altitude regions: boundary layer (BL) $<2 \mathrm{~km}$ and free troposphere $(\mathrm{FT})>2 \mathrm{~km}$.

the GABRIEL campaign. The performance of the LIF instrument for the detection of $\mathrm{OH}$ and $\mathrm{HO}_{2}$ is also discussed in Martinez et al. (2010).

The rate constants of the used chemical mechanism of MECCA correspond to former recommendations and the rate constants should be updated in further studies. The recommended rate coefficients of Sander et al. (2006) for $\mathrm{O}\left({ }^{1} \mathrm{D}\right)+\mathrm{H}_{2} \mathrm{O}, \mathrm{O}\left({ }^{1} \mathrm{D}\right)+\mathrm{O}_{2}, \mathrm{O}\left({ }^{1} \mathrm{D}\right)+\mathrm{N}_{2}$, compared to Sander et al. (2003) account for a $12 \%$ reduction of $\mathrm{OH}$ and a $5 \%$ reduction for $\mathrm{HO}_{2}$. For our studies, this effect lies within our uncertainty and does not change our conclusions. Therefore, to be consistent with Stickler et al. (2007), who analysed the GABRIEL data with a different focus on HCHO, MECCA v0.1p was used.

\subsection{Correlation with isoprene}

Comparison between observations and model simulations for $\mathrm{OH}$ and $\mathrm{HO}_{2}$ with respect to the diurnal cycle, shows that model underestimations are relatively large in the afternoon, especially in the boundary layer (Fig. 10). Emissions of
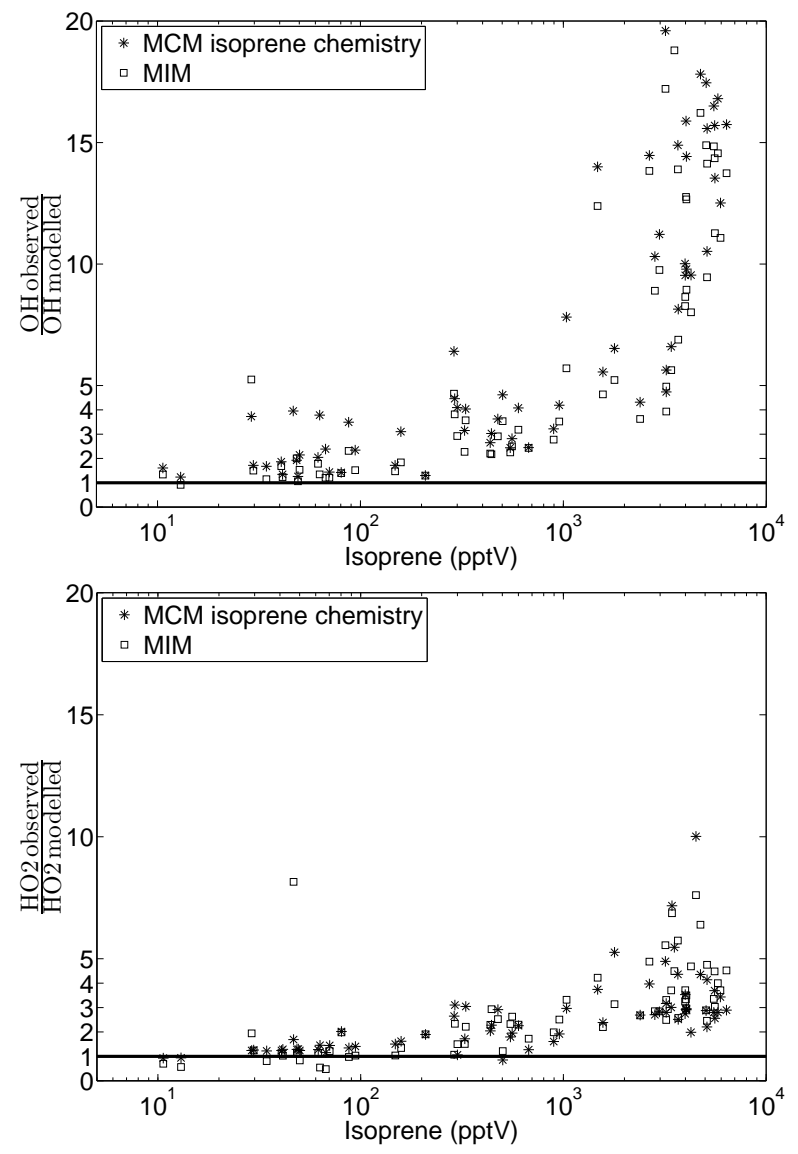

Fig. 12. Deviations between observations and model results as a function of isoprene mixing ratios. 
Table 5. Isoprene mechanism in MECCA. The entire chemical mechanism is described in the accompanying Supplement.

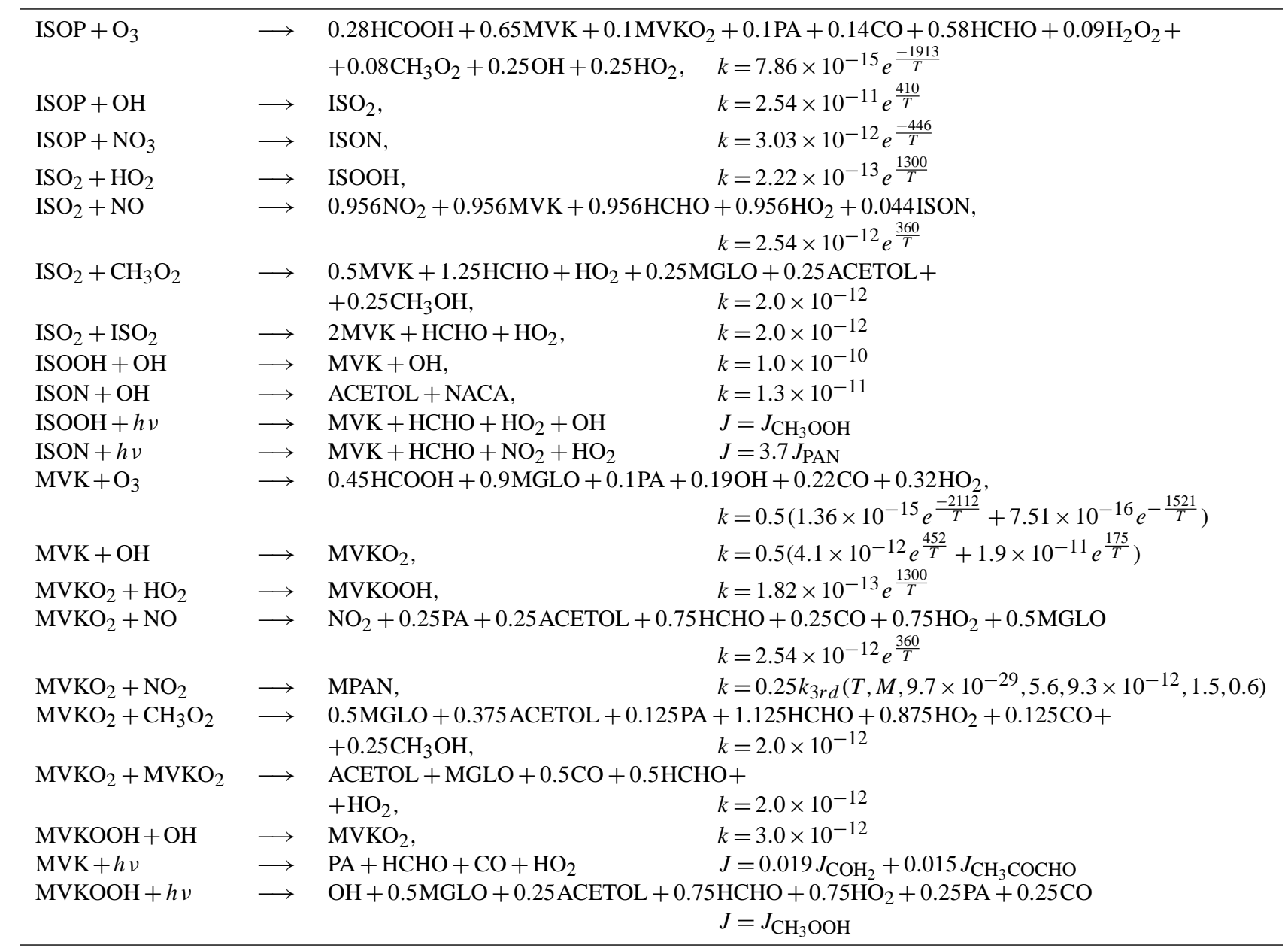

$\mathrm{ISOP}=$ isoprene, $\mathrm{ISO}_{2}=$ isoprene (hydroxy) peroxy radicals, ISOOH $=$ isoprene (hydro) peroxides, ISON $=$ organic nitrates from $\mathrm{ISO}_{2}$ and $\mathrm{ISOP}+\mathrm{NO}_{3}, \quad \mathrm{MVK}=$ methylvinylketone + methacrolein, $\quad \mathrm{MVKO}_{2}=\mathrm{MVK} / \mathrm{MACR}$ peroxy radicals, $\mathrm{MVKOOH}=\mathrm{MVK} / \mathrm{MACR}$ hydroperoxides, $\mathrm{MGLO}=$ methylglyoxal, $\mathrm{PA}=$ peroxy acetyl radical, NACA = nitro-oxy acetaldehyde, MPAN=peroxymethacryloyl nitrate + peroxymethacrylic nitric anhydride, ACETOL=hydroxy acetone. Reactions are taken from the MECCA v0.1p. $k_{3 \mathrm{rd}}\left(T,[M], k_{0}^{300}, n, k_{\infty}^{300}, m, f_{c}\right)=k_{0}(T)[M]\left(1+\frac{k_{0}(T)[M]}{k_{\infty}(T)}\right)^{-1} f_{c}^{\left\{1+\lg ^{2}\left(\frac{k_{0}(T)[M]}{k_{\infty}(T)}\right)\right\}^{-1}}, k_{0}(T)=k_{0}^{300}\left(\frac{300}{T}\right)^{n}, k_{\infty}(T)=k_{\infty}^{300}\left(\frac{300}{T}\right)^{m}$.

hydrocarbons from the rainforest are driven by light and temperature. The most abundant VOC species over the rainforest is isoprene (Guenther et al., 1995; Granier et al., 2000), the concentration of which increases strongly towards the afternoon (Fig. 11) (Eerdekens et al., 2008; Warneke et al., 2001). The initial reactions of the isoprene oxidation scheme in MECCA are given in Table 5.

The ratio of observation to model results for both $\mathrm{OH}$ and $\mathrm{HO}_{2}$ as a function of the mixing ratio of isoprene is indeed clearly correlated, as shown in Fig. 12. For isoprene mixing ratios below $200 \mathrm{pptV}$, the ratios of observation to model concentrations vary around $1.4 \pm 0.4$ for $\mathrm{OH}$ and $1.0 \pm 0.4$ for $\mathrm{HO}_{2}$, whereas for mixing ratios greater than $200 \mathrm{pptV}$ the model increasingly underestimates the $\mathrm{HO}_{\mathrm{x}}$ concentrations by more than a factor of 2 . Dividing into isoprene logarithmic bins of $\Delta \ln x=0.5, x$ : isoprene mixing ratio, leads to maximum observed to modelled ratios of $13 \pm$ $2(\mathrm{OH})$ and $3.7 \pm 0.8\left(\mathrm{HO}_{2}\right)$ for the highest isoprene mixing ratios of $5.6 \pm 0.4 \mathrm{ppbV}$. A similar observation was made by Ren et al. (2008), who measured $\mathrm{HO}_{\mathrm{x}}$ over a forest in the northern mid-latitudes. Their photochemical box model (Crawford et al., 1999) overestimated $\mathrm{OH}$ for isoprene mixing ratios lower than $500 \mathrm{pptV}$, and increasingly underestimated the concentrations for isoprene levels exceeding $500 \mathrm{pptV}$. Although the absolute values differ from the GABRIEL studies, the performance of both models shows a similar tendency with respect to isoprene. The coincidence of the qualitative behaviour of the two 
Table 6. Sensitivity studies of the photolysis frequencies concerning the isoprene chemistry of the MCM. Concentrations are mean values for the forest boundary layer $(<1 \mathrm{~km})$ in the afternoon $(14-17 \mathrm{LT})$.

\begin{tabular}{|c|c|c|c|c|c|c|}
\hline & $\begin{array}{c}\mathrm{OH} \\
\left(\mathrm{molec} / \mathrm{cm}^{3}\right)\end{array}$ & $1 \sigma(\%)$ & $\begin{array}{c}\mathrm{OH} \\
\mathrm{obs} / \mathrm{mod}\end{array}$ & $\begin{array}{c}\mathrm{HO}_{2} \\
\left(\mathrm{molec} / \mathrm{cm}^{3}\right)\end{array}$ & $1 \sigma(\%)$ & $\begin{array}{c}\mathrm{HO}_{2} \\
\mathrm{obs} / \mathrm{mod}\end{array}$ \\
\hline Observation & $43.9 \times 10^{5}$ & 21 & 1.0 & $10.2 \times 10^{8}$ & 19 & 1.0 \\
\hline Reference Run & $3.71 \times 10^{5}$ & 26 & $13.2 \pm 3.9$ & $3.00 \times 10^{8}$ & 23 & $3.8 \pm 1.3$ \\
\hline $10^{3} \times \mathrm{J}\left(\mathrm{MACR}_{18}\right)^{\mathrm{a}}$ & $2.48 \times 10^{5}$ & 39 & $21.5 \pm 10.4$ & $32.2 \times 10^{8}$ & 21 & $0.4 \pm 0.1$ \\
\hline $10^{-3} \times \mathrm{J}\left(\mathrm{MACR}_{18}\right)$ & $3.67 \times 10^{5}$ & 27 & $13.3 \pm 3.9$ & $2.84 \times 10^{8}$ & 24 & $4.0 \pm 1.4$ \\
\hline $10^{3} \times \mathrm{J}\left(\mathrm{MACR}_{19}\right)^{\mathrm{b}}$ & $0.17 \times 10^{5}$ & 47 & $338 \pm 183$ & $29.6 \times 10^{8}$ & 21 & $0.4 \pm 0.1$ \\
\hline $10^{-3} \times \mathrm{J}\left(\mathrm{MACR}_{19}\right)$ & $3.71 \times 10^{5}$ & 26 & $13.2 \pm 3.8$ & $2.79 \times 10^{8}$ & 24 & $3.9 \pm 1.4$ \\
\hline $10^{3} \times \mathrm{J}\left(\mathrm{MVK}_{24}\right)^{\mathrm{c}}$ & $4.48 \times 10^{5}$ & 26 & $11.0 \pm 3.7$ & $8.79 \times 10^{8}$ & 22 & $1.3 \pm 0.5$ \\
\hline $10^{-3} \times \mathrm{J}\left(\mathrm{MVK}_{24}\right)$ & $3.71 \times 10^{5}$ & 26 & $13.2 \pm 3.9$ & $2.99 \times 10^{8}$ & 23 & $3.8 \pm 1.3$ \\
\hline $10^{3} \times \mathrm{J}(\mathrm{ISOPBOOH})^{\mathrm{d}}$ & $4.62 \times 10^{5}$ & 26 & $10.5 \pm 2.9$ & $3.73 \times 10^{8}$ & 21 & $3.0 \pm 1.0$ \\
\hline $10^{-3} \times \mathrm{J}(\mathrm{ISOPBOOH})$ & $3.68 \times 10^{5}$ & 26 & $13.3 \pm 4.0$ & $2.97 \times 10^{8}$ & 24 & $3.8 \pm 1.3$ \\
\hline $10^{3} \times \mathrm{J}(\mathrm{ISOPDOOH})^{\mathrm{e}}$ & $4.16 \times 10^{5}$ & 26 & $11.7 \pm 3.4$ & $3.27 \times 10^{8}$ & 23 & $3.5 \pm 1.2$ \\
\hline $10^{-3} \times \mathrm{J}(\mathrm{ISOPDOOH})$ & $3.70 \times 10^{5}$ & 26 & $13.2 \pm 3.9$ & $2.99 \times 10^{8}$ & 23 & $3.8 \pm 1.3$ \\
\hline $10^{3} \times \mathrm{J}\left(\mathrm{CH}_{3} \mathrm{OOH}_{41}\right)^{\mathrm{f}}$ & $4.06 \times 10^{5}$ & 25 & $12.0 \pm 3.4$ & $3.29 \times 10^{8}$ & 22 & $3.4 \pm 1.1$ \\
\hline $10^{-3} \times \mathrm{J}\left(\mathrm{CH}_{3} \mathrm{OOH}_{41}\right)$ & $3.70 \times 10^{5}$ & 26 & $13.2 \pm 3.9$ & $2.98 \times 10^{8}$ & 24 & $3.8 \pm 1.3$ \\
\hline
\end{tabular}

${ }^{\mathrm{a}} \mathrm{MACR}+\mathrm{h} v \longrightarrow \mathrm{CH}_{3} \mathrm{CO}_{3}+\mathrm{HCHO}+\mathrm{CO}+\mathrm{HO}_{2}$

${ }^{\mathrm{b}} \mathrm{MACR}+\mathrm{h} v \longrightarrow \mathrm{MACO}_{3}+\mathrm{HO}_{2}$

${ }^{\mathrm{c}} \mathrm{MVK}+\mathrm{h} v \longrightarrow \mathrm{CH}_{3} \mathrm{CO}_{3}+\mathrm{HCHO}+\mathrm{CO}+\mathrm{HO}_{2}$

${ }^{\mathrm{d}} \mathrm{ISOPBOOH}+\mathrm{h} v \longrightarrow \mathrm{ISOPBO}+\mathrm{OH} ; \mathrm{J}(\mathrm{ISOPBOOH})=\mathrm{J}\left(\mathrm{CH}_{3} \mathrm{OOH}_{41}\right)$

${ }^{\mathrm{e}}$ ISOPDOOH $+\mathrm{h} v \longrightarrow \mathrm{ISOPDO}+\mathrm{OH} ; \mathrm{J}(\mathrm{ISOPDOOH})=\mathrm{J}\left(\mathrm{CH}_{3} \mathrm{OOH}_{41}\right)$

${ }^{\mathrm{f}} \mathrm{CH}_{3} \mathrm{OOH}+\mathrm{h} v \longrightarrow \mathrm{CH}_{3} \mathrm{O}+\mathrm{OH}$

different box models for different field campaigns points either to a more fundamental gap in our knowledge of the isoprene degradation mechanism or to missing sources of $\mathrm{OH}$ with the same emission behaviour as isoprene.

\subsection{Simulation with the Master Chemical Mechanism MCM}

To test the performance of the lumped mechanism MIM, the more detailed isoprene chemistry of the MCM (Pinho et al., 2005) was included in the box model MECCA for comparison. More species (213 in total) were taken into account and the reaction scheme included several additional photolytic reactions. As the absorption cross sections and the quantum yields were not available for all implemented species, the photolysis frequencies (J) could not be calculated with the TUV model. Therefore, photolysis frequencies for species for which this information was available were used for all species of similar chemical structure as grouped in the MCM. The resulting photolysis frequencies are very uncertain, therefore sensitivity studies concerning the photolytic reactions were performed by varying the J-values by a factor of $10^{-3}$ and $10^{3}$. In order to avoid possible overestimation of $\mathrm{H}_{2} \mathrm{O}_{2}$, only the datasets with measured peroxide data available were taken into account. In Table 6 , the photolytic reactions with the strongest effect on $\mathrm{OH}$ (more than 10\% compared to the base run) are listed. The photolysis frequencies of the two isomers of the isoprene peroxy radical (2-hydroperoxy-2-methylbut-3-en-1-ol (ISOPBOOH) and 2-hydroperoxy-3-methylbut-3-en-1-ol (ISOPDOOH)) were the most prominent. As recommended in the MCM, the photolysis frequency of $\mathrm{CH}_{3} \mathrm{OOH}$ was used for the analysis, calculated with the absorption cross section given by Vaghjiani et al. (1989) with quantum yields of unity. Increasing this photolysis frequency by a factor of $10^{3}$ enhanced $\mathrm{OH}$ and $\mathrm{HO}_{2}$ concentrations by $24 \%$. Reduction of any of these frequencies by a factor of $10^{-3}$ led to a maximum reduction of $2 \%$ in $\mathrm{OH}$. Thus, photolysis reactions in the model with unknown photolysis frequencies, with respect to $\mathrm{OH}$ and $\mathrm{HO}_{2}$, were not relevant unless the photolysis frequencies were very strongly underestimated.

Variation of the photolysis of methacrolein (MACR) has a strong impact on $\mathrm{OH}$. However, the absorption cross sections for methylvinylketone (MVK) and MACR have been measured (Gierczak et al., 1997). The variation of a factor $10^{3}$ was unrealistically high but emphasizes the effect of the photolysis products. Increasing the photolysis frequency of MACR by $10^{3}$ led to a large underestimation of $\mathrm{OH}$ (Table 6), indicating that the products deplete $\mathrm{OH}$ in further reactions.

During GABRIEL only the total sum of MVK and MACR was measured. For the studies with the MCM mechanism, these two species are treated separately. A ratio of MVK: 


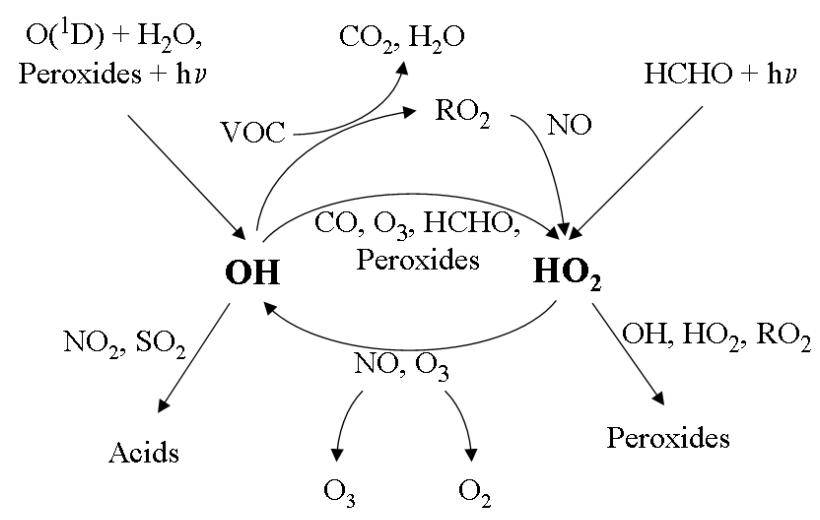

Fig. 13. Schematic representation of $\mathrm{HO}_{\mathrm{x}}$ cycling.

MACR $=2: 1$ was used (Kuhn et al., 2007). Simulations with ratios of MVK : MACR $=0: 1$ and 1:0 changed the $\mathrm{OH}$ concentration about $-5 \%$ and $+3 \%$, the $\mathrm{HO}_{2}$ concentration $+20 \%$ and $-10 \%$, respectively. In MIM the two species are lumped together.

Although 493 more explicit reactions were considered in the extensive isoprene chemistry scheme of the MCM, similar results were obtained as for the lumped mechanism MIM (Fig. 12). The reduced chemical mechanism of MIM was developed on the basis of the MCM (Poeschl et al., 2000) and the results in Fig. 12 confirm that the MIM performs well within the original objective. Neither the simplification of the MIM chemistry nor the assumptions made for the MCM simulations explained the discrepancies between models and observations. Possible explanations might lead to more fundamental chemistry (Taraborrelli et al., 2009) or e.g. to segregation effects (Butler et al., 2008).

\subsection{Testing the $\mathrm{HO}_{\mathrm{x}}$ cycling mechanism in MECCA}

The $\mathrm{HO}_{\mathrm{x}}$ cycling mechanisms are illustrated in Fig. 13. In the remote troposphere $\mathrm{OH}$ is converted to $\mathrm{HO}_{2}$ mainly via carbon monoxide and recycled from $\mathrm{HO}_{2}$ by reactions with nitric oxide and ozone. However over the rainforest, $\mathrm{OH}$ is removed by reactions with the emitted VOC, producing peroxy radicals. These peroxy radicals react either with other peroxy radicals or $\mathrm{NO}$ forming $\mathrm{HO}_{2}$, or with $\mathrm{HO}_{2}$ producing peroxides. Total radical loss from the radical cycle occurs by removing $\mathrm{OH}, \mathrm{RO}_{2}$ and $\mathrm{HO}_{2}$ from the system. One major loss pathway over the rainforest is the formation of organic peroxides. Although the photolysis of peroxides is also a source of radicals, this channel is minor compared to the radical production via photolysis of ozone and reaction with water vapour, or the photolysis of HCHO. Organic peroxides are also removed from the system by dry deposition (Stickler et al., 2007).

One possible reason for the underestimation of $\mathrm{OH}$ and $\mathrm{HO}_{2}$ in the model is an overestimation of modelled radical removal through the production of organic peroxides, especially the peroxides of isoprene and MACR+MVK (ISOOH, MVKOOH). Thornton et al. (2002) could explain their results from the SOS 1999 campaign (Nashville) for low $\mathrm{NO}_{\mathrm{x}}$ conditions by a decrease in the effective peroxide formation rate $\left(\mathrm{RO}_{2}+\mathrm{HO}_{2} \longrightarrow \mathrm{ROOH}\right)$, which either means a reduction of the rate coefficient or a partitioning in an additional reaction e.g. $\mathrm{RO}_{2}+\mathrm{HO}_{2} \longrightarrow \mathrm{RO}+\mathrm{OH}+$ $\mathrm{O}_{2}$. The latter has a functional equivalent to assumed rapid photolysis of $\mathrm{ROOH}$. They found the best agreement for a decreasing factor of 10 in their box model. For the GABRIEL campaign about $50 \%$ of all $\mathrm{RO}_{2}$ form $\mathrm{ROOH}$, the other $50 \%$ forming $\mathrm{HO}_{2}$ (branching ratio: $\left.\left(\mathrm{RO}_{2} \rightarrow \mathrm{ROOH}\right) /\left(\mathrm{RO}_{2} \rightarrow \mathrm{HO}_{2}+\mathrm{HCHO}\right)=1.0 \pm 0.2\right)$ for isoprene mixing ratios $>2 \mathrm{ppbV}$, which are typical for the afternoon over the rainforest at altitudes below $1 \mathrm{~km}$. Since photolysis of organic peroxides is negligible for radical production, as it is described by the chemical mechanism of MECCA, the sensitivity of $\mathrm{HO}_{\mathrm{x}}$ to the reaction rate of $\mathrm{HO}_{2}$ with $\mathrm{RO}_{2}$ can be investigated by taking these reactions out of the model.

For the $\mathrm{HO}_{2}$ concentration this modified simulation leads to an enhancement factor of $2.5 \pm 0.2$ at maximum isoprene mixing ratios of $(5.6 \pm 0.4) \mathrm{ppbV}$, improving the comparison with the observation. However the influence on $\mathrm{OH}$ is small, leading to an increase only by a factor of $1.2 \pm 0.1$.

By constraining the $\mathrm{HO}_{2}$ concentration to the observations, $\mathrm{OH}$ increases only by a factor of $1.7 \pm 0.2$. Thus the enhancement of $\mathrm{HO}_{2}$ in the model does not imply an increase of $\mathrm{OH}$ sufficient to describe the observations, which instead requires additional recycling from $\mathrm{HO}_{2}$ to $\mathrm{OH}$ in the model or additional direct sources for $\mathrm{OH}$, as also proposed by Tan et al. (2001).

An additional $\mathrm{OH}$ recycling reaction, $\mathrm{HO}_{2}+\mathrm{X} \longrightarrow \mathrm{OH}+$ $\mathrm{X}^{\prime}$, is a possible pathway to increase the simulated $\mathrm{OH}$ concentration. As proposed by Thornton et al. (2002) and confirmed by the laboratory work of Hasson et al. (2004), certain alkyl peroxy radicals react with $\mathrm{HO}_{2}$ yielding $\mathrm{OH}$ :

$$
\begin{aligned}
\mathrm{RO}_{2}+\mathrm{HO}_{2} & \longrightarrow \mathrm{ROOH}+\mathrm{O}_{2}, \\
& \longrightarrow \mathrm{ROH}+\mathrm{O}_{3}, \\
& \longrightarrow \mathrm{RO}+\mathrm{OH}+\mathrm{O}_{2} .
\end{aligned}
$$

Such reactions would also decrease the organic peroxides which were overestimated by MECCA for GABRIEL (Stickler et al., 2007). Hasson et al. (2004) examined the additional Reaction (R8) for ethyl peroxy $\left(\mathrm{C}_{2} \mathrm{H}_{5} \mathrm{O}_{2}\right)$, acetyl peroxy $\left(\mathrm{CH}_{3} \mathrm{C}(\mathrm{O}) \mathrm{O}_{2}\right)$ and acetonyl peroxy $\left(\mathrm{CH}_{3} \mathrm{C}(\mathrm{O}) \mathrm{CH}_{2} \mathrm{O}_{2}\right)$ radicals, finding a yield of $40 \%$ for acetyl peroxy radicals. Further studies concerning this type of reaction by Dillon et al. (2008) and Jenkin et al. (2007) showed similar results and typical yields of about $50 \%$ or higher. To assess the effect of this additional $\mathrm{OH}$ recycling, all $\mathrm{RO}_{2}$ reactions with $\mathrm{HO}_{2}$ were modified in MECCA without distinction between different species. The 
branching ratio was varied between $50 \%$ and $90 \%$, the latter obviously an upper limit. Nevertheless, even for the largest branching ratio the observed $\mathrm{OH}$ concentrations are still not reproduced. For the highest observed isoprene mixing ratios of $(5.6 \pm 0.4) \mathrm{ppbV}$ the modification of MECCA produces maximum factors of $1.42 \pm 0.04$ and $2.42 \pm 0.24$ more $\mathrm{OH}$ for yields of $50 \%$ and $90 \%$ compared to the base runs (Fig. 14). This effect is still too small compared to the factors up to 13 needed to reproduce the measured $\mathrm{OH}$ concentrations under conditions of high isoprene. For $\mathrm{HO}_{2}$ similar enhancement factors are obtained with $1.35 \pm 0.06$ and $1.99 \pm 0.21$ for the two $\mathrm{OH}$ yields, while factors of 3.7 are needed to reproduce the observations.

Another possible source of $\mathrm{OH}$ is the photolysis of organic peroxy radicals by near-infrared radiation via intramolecular rearrangement producing $\mathrm{OH}$ or $\mathrm{HO}_{2}$ (Frost et al., 1999):

$$
\begin{aligned}
\mathrm{RO}_{2}+h v & \longrightarrow \mathrm{R}^{\prime} \mathrm{O}+\mathrm{OH}, \\
& \longrightarrow \mathrm{R}^{\prime \prime}+\mathrm{HO}_{2} .
\end{aligned}
$$

The photolysis frequency was assumed to follow that of $\mathrm{NO}_{3}$ with values of $10^{-3}$ to $10^{-1} \times \mathrm{J}\left(\mathrm{NO}_{3}\right)$. The additional photochemical reactions were implemented in the model for all $\mathrm{RO}_{2}$ to produce $100 \% \mathrm{OH}$ via Reaction (R9), while no reaction channel to produce $\mathrm{HO}_{2}$ was included. The highest photolysis frequency was chosen for the simulation shown here to obtain an upper limit (Fig. 14). For isoprene mixing ratios of $(5.6 \pm 0.4) \mathrm{ppbV}$ the model with the additional chemistry leads to enhancement factors of $2.65 \pm 0.56$ for $\mathrm{OH}$ and $1.08 \pm 0.02$ for $\mathrm{HO}_{2}$ compared to the base run. This is again insufficient to reproduce the observed $\mathrm{HO}_{\mathrm{x}}$ concentrations, even though the results represent an upper limit.

None of the proposed reaction amendments alone is sufficient to reproduce the measured data in the model. As a further step, both $\mathrm{OH}$ recycling reaction of $\mathrm{RO}_{2}$ with $\mathrm{HO}_{2}$ and infrared photolysis of $\mathrm{RO}_{2}$ were included in the model reaction scheme with maximum yields for $\mathrm{OH}(90 \%$ yield for Reaction (R8) and $10^{-1} \cdot \mathrm{J}\left(\mathrm{NO}_{3}\right)$ for Reaction (R9)). Even then, simulated $\mathrm{HO}_{\mathrm{x}}$ remains too low with enhancement factors of $5.1 \pm 1.1$ for $\mathrm{OH}$ and $2.1 \pm 0.2$ for $\mathrm{HO}_{2}$.

Searching for alternative reactions which leads to $\mathrm{OH}$ production and at the same time to a reduction of peroxides is a promising way to explain the measurements over the tropical rainforest. By constraining the box model with the observed $\mathrm{OH}$ and $\mathrm{HO}_{2}$-concentrations overestimation of $\mathrm{HCHO}$ and peroxides could be found (Stickler et al., 2007). In this case isoprene oxidation produces more peroxy radicals and therefore more peroxides are produced. Alternative isoprene mechanisms, which reduce $\mathrm{RO}_{2}$ and $\mathrm{ROOH}$ formation and were tested above, going in the right direction, but on its own are still not powerful enough.
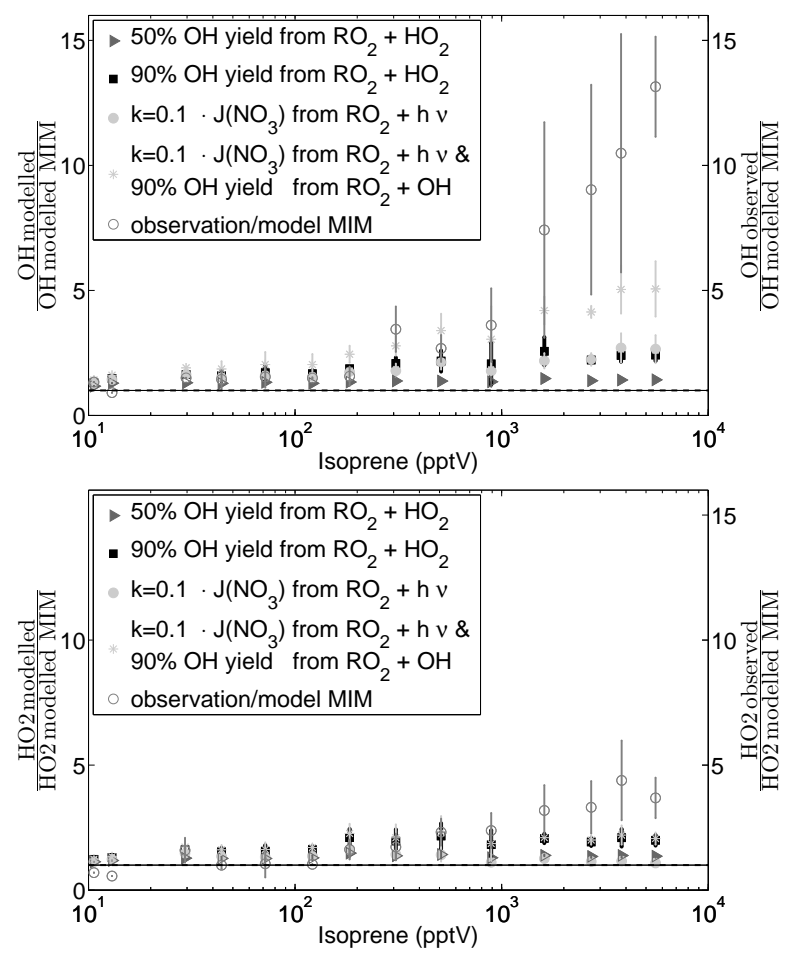

Fig. 14. Comparison of observed and modelled $\mathrm{HO}_{\mathrm{x}}$ based on selected changes in the MECCA chemistry scheme. Values are binned in isoprene mixing ratios $(\mathrm{x})$ of $\Delta \ln x=0.5$.

Ozonolysis of monoterpenes can also be an $\mathrm{OH}$ source (Tan et al., 2001) and is not considered in the model. As monoterpene emissions show a similar diurnal dependence as those of isoprene (Williams et al., 2007) their contribution to the $\mathrm{OH}$ concentration over the rainforest would be strongest in the afternoon. For the GABRIEL campaign $\alpha$ - and $\beta$-pinene were measured with maximum mixing ratios of the order of $200 \mathrm{pptV}$. Ozonolysis of monoterpenes was estimated to be about $10^{5}$ molec $\mathrm{cm}^{-3} \mathrm{~s}^{-1}$ (Atkinson et al., 2005) over the rainforest in the afternoon, which is negligible compared to the primary production term (R1) of $3 \times 10^{6} \mathrm{molec} \mathrm{cm}^{-3} \mathrm{~s}^{-1}$. The influence of monoterpenes and sesquiterpenes has been studied in detail by Ganzeveld et al. (2008), who compared the GABRIEL data with a single-column model, also concluding that ozonolysis of these species does not eliminate the large discrepancies between modelled and observed $\mathrm{OH}$.

\section{$4.4 \mathrm{HO}_{\mathrm{x}}$ budget}

An overview of the most relevant reactions for the $\mathrm{HO}_{\mathrm{x}}$ budget in MECCA is given in Tables 7 and 8 to identify the main processes of the production and loss terms of $\mathrm{OH}$ and $\mathrm{HO}_{2}$ for four groups of data. Case 1 is based on observations in the boundary layer over the rainforest, at altitudes lower than $1 \mathrm{~km}$, in the morning $(8-11 \mathrm{LT})$. Data from the same 
Table 7. OH budget based on a model analysis of measurement data.

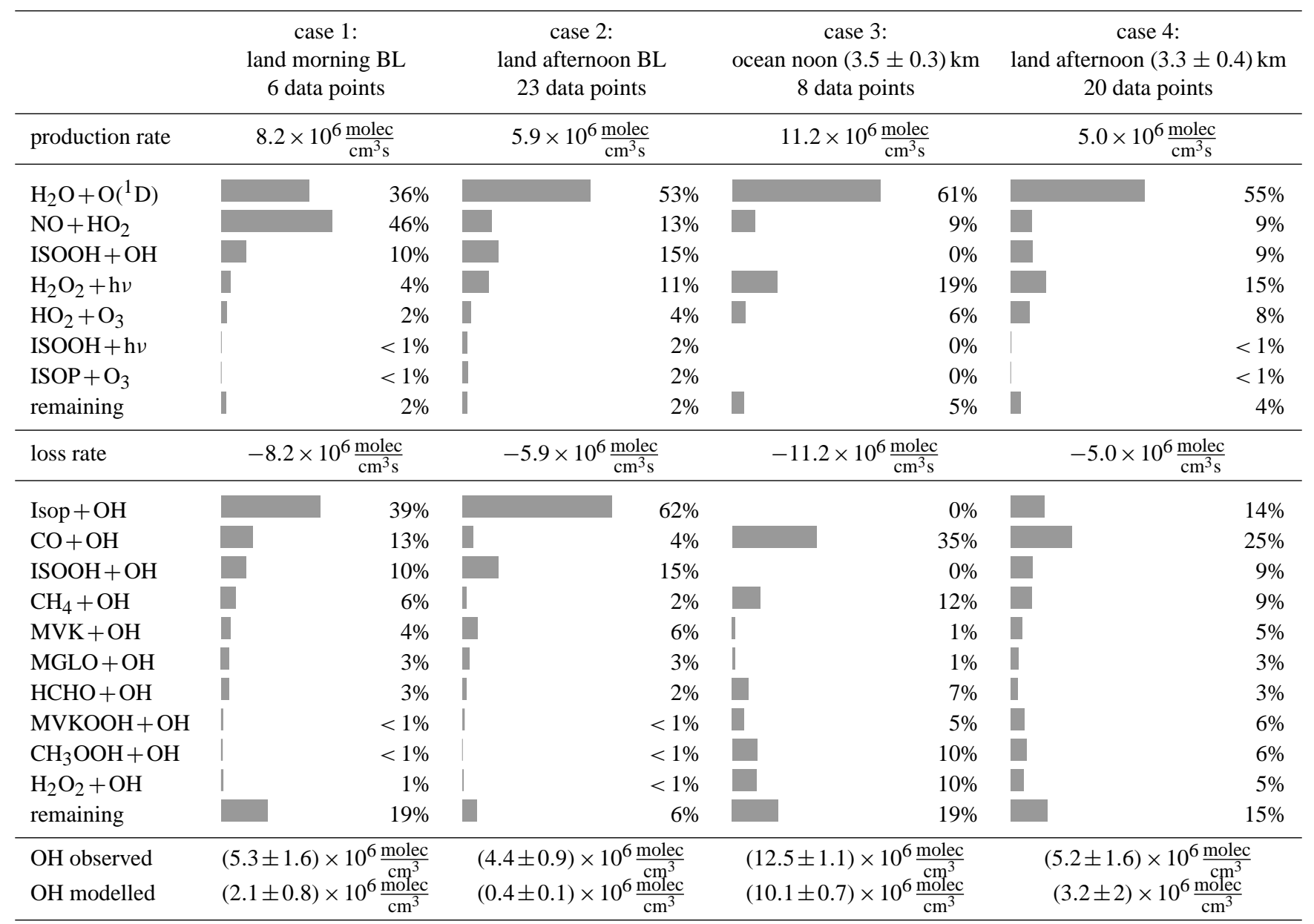

location in the afternoon (14-17 LT) are analysed in the second group. Data from the free troposphere over the ocean at an altitude of 2-4 km around noon (11-14 LT ) are used for case 3, and data collected over the rainforest in the afternoon at the same altitude for case 4 . Only the cases with at least 6 data points are discussed. Data at altitudes higher than $4 \mathrm{~km}$ 's are not considered, owing to the unavailability of measurements of peroxides, which become important for $\mathrm{HO}_{\mathrm{x}}$ chemistry as $\mathrm{H}_{2} \mathrm{O}$ concentrations decrease. The averaged concentrations of the species, which were used to constrain the simulations, are shown in Table 9.

The primary production of $\mathrm{OH}$ in the lower troposphere is the photolysis of ozone followed by reaction with water vapour. Primary production rates are of the order of $40 \%-60 \%$ of the total production. The NO mixing ratios are highest in the morning boundary layer over the forest with $(65 \pm 57) \mathrm{pptV}$, compared to $(13 \pm 9) \mathrm{pptV},(10 \pm 3) \mathrm{pptV}$ and $(8 \pm 4) \mathrm{pptV}$ for the other three cases, respectively. In the morning, solar radiation is still low and the $\mathrm{OH}$ radical recycling by reaction $\mathrm{NO}+\mathrm{HO}_{2}$ is comparable with the primary $\mathrm{OH}$ source. For all other cases the $\mathrm{OH}$ recycling via reaction of $\mathrm{HO}_{2}$ is weak compared to the primary production. As the emissions of BVOCs increase during daytime, these compounds and their oxidation products increasingly influence the $\mathrm{OH}$ chemistry. The recycling of $\mathrm{OH}$ via the reactions of isoprene peroxides $\mathrm{ISOOH}+\mathrm{OH}^{2}$ in MIM is one of the major conversion mechanisms in MECCA and illustrates their importance to the chemistry of isoprene.

The loss of $\mathrm{OH}$ in the boundary layer, according to MECCA, is dominated by the reaction with isoprene. As isoprene concentrations increase during the day, the proportion of this reaction with respect to the total loss increases to $62 \%$ in the afternoon and is even more important than the primary production term (53\%). When less isoprene is available, the removal of $\mathrm{OH}$ by $\mathrm{CO}$ and peroxides becomes more significant.

\footnotetext{
${ }^{2} \mathrm{ISOOH}+\mathrm{OH} \rightarrow \mathrm{MVK}+\mathrm{OH}$
} 
Table 8. $\mathrm{HO}_{2}$ budget based on a model analysis of measurement data.

\begin{tabular}{|c|c|c|c|c|c|c|c|c|}
\hline & \multicolumn{2}{|c|}{$\begin{array}{c}\text { case 1: } \\
\text { land morning BL } \\
6 \text { data points }\end{array}$} & \multicolumn{2}{|c|}{$\begin{array}{c}\text { case 2: } \\
\text { land afternoon BL } \\
23 \text { data points }\end{array}$} & \multicolumn{2}{|c|}{$\begin{array}{c}\text { case } 3: \\
\text { ocean noon }(3.5 \pm 0.3) \mathrm{km} \\
8 \text { data points }\end{array}$} & \multicolumn{2}{|c|}{$\begin{array}{c}\text { case } 4: \\
\text { land afternoon }(3.3 \pm 0.4) \mathrm{km} \\
20 \text { data points }\end{array}$} \\
\hline production rate & \multicolumn{2}{|c|}{$6.4 \times 10^{6} \frac{\mathrm{molec}}{\mathrm{cm}^{3} \mathrm{~s}}$} & \multicolumn{2}{|c|}{$4.3 \times 10^{6} \frac{\mathrm{molec}}{\mathrm{cm}^{3} \mathrm{~s}}$} & \multicolumn{2}{|c|}{$9.2 \times 10^{6} \frac{\mathrm{molec}}{\mathrm{cm}^{3} \mathrm{~s}}$} & \multicolumn{2}{|c|}{$3.4 \times 10^{6} \frac{\mathrm{molec}}{\mathrm{cm}^{3} \mathrm{~s}}$} \\
\hline $\mathrm{HCHO}+\mathrm{h} v$ & L & $13 \%$ & & $36 \%$ & - & $15 \%$ & L & $18 \%$ \\
\hline $\mathrm{CO}+\mathrm{OH}$ & L & $17 \%$ & D & $6 \%$ & & $42 \%$ & & $35 \%$ \\
\hline $\mathrm{ISO}_{2}+\mathrm{NO}$ & & $32 \%$ & - & $22 \%$ & & $0 \%$ & I & $3 \%$ \\
\hline $\mathrm{ISO}_{2}+\mathrm{ISO}_{2}$ & I & $1 \%$ & $\square$ & $8 \%$ & & $0 \%$ & | & $<1 \%$ \\
\hline $\mathrm{CH}_{3} \mathrm{O}_{2}+\mathrm{NO}$ & 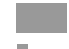 & $15 \%$ & 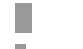 & $5 \%$ & 口 & $6 \%$ & $\square$ & $8 \%$ \\
\hline $\mathrm{MVKO}_{2}+\mathrm{NO}$ & 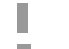 & $3 \%$ & 1 & $3 \%$ & | & $<1 \%$ & I & $2 \%$ \\
\hline $\mathrm{HCHO}+\mathrm{OH}$ & I & $4 \%$ & I & $2 \%$ & a & $8 \%$ & 【 & $4 \%$ \\
\hline $\mathrm{ISOOH}+\mathrm{h} v$ & & $<1 \%$ & I & $3 \%$ & & $0 \%$ & & $<1 \%$ \\
\hline $\mathrm{CH}_{3} \mathrm{H}_{6} \mathrm{O}_{2}+\mathrm{NO}$ & 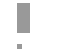 & $4 \%$ & I & $<1 \%$ & & $0 \%$ & & $<1 \%$ \\
\hline $\mathrm{H}_{2} \mathrm{O}_{2}+\mathrm{OH}$ & I & $1 \%$ & | & $<1 \%$ & & $12 \%$ & 口 & $8 \%$ \\
\hline remaining & 口 & $14 \%$ & 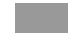 & $16 \%$ & & $16 \%$ & & $22 \%$ \\
\hline loss rate & \multicolumn{2}{|c|}{$-6.4 \times 10^{6} \frac{\mathrm{molec}}{\mathrm{cm}^{3} \mathrm{~s}}$} & \multicolumn{2}{|c|}{$-4.3 \times 10^{6} \frac{\mathrm{molec}}{\mathrm{cm}^{3} \mathrm{~s}}$} & \multicolumn{2}{|c|}{$-9.2 \times 10^{6} \frac{\mathrm{molec}}{\mathrm{cm}^{3} \mathrm{~s}}$} & \multicolumn{2}{|c|}{$-3.4 \times 10^{6} \frac{\mathrm{molec}}{\mathrm{cm}^{3} \mathrm{~s}}$} \\
\hline $\mathrm{NO}+\mathrm{HO}_{2}$ & t & $59 \%$ & & $17 \%$ & 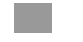 & $12 \%$ & 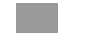 & $13 \%$ \\
\hline $\mathrm{HO}_{2}+\mathrm{O}_{3}$ & I & $3 \%$ & I & $5 \%$ & [ & $7 \%$ & L & $11 \%$ \\
\hline $\mathrm{ISO}_{2}+\mathrm{HO}_{2}$ & L & $15 \%$ & & $44 \%$ & & $0 \%$ & 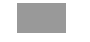 & $15 \%$ \\
\hline $\mathrm{HO}_{2}+\mathrm{HO}_{2}$ & & $17 \%$ & & $21 \%$ & & $48 \%$ & & $30 \%$ \\
\hline $\mathrm{CH}_{3} \mathrm{O}_{2}+\mathrm{HO}_{2}$ & I & $2 \%$ & I & $3 \%$ & & $16 \%$ & $\square$ & $13 \%$ \\
\hline $\mathrm{MVKO}_{2}+\mathrm{HO}_{2}$ & I & $2 \%$ & $\square$ & $6 \%$ & 口 & $6 \%$ & 口 & $11 \%$ \\
\hline $\mathrm{HO}_{2}+\mathrm{OH}$ & I & $1 \%$ & & $<1 \%$ & 口 & $9 \%$ & I & $4 \%$ \\
\hline remaining & I & $1 \%$ & I & $1 \%$ & I & $2 \%$ & I & $3 \%$ \\
\hline $\begin{array}{l}\mathrm{HO}_{2} \text { observed } \\
\mathrm{HO}_{2} \text { modelled }\end{array}$ & \multicolumn{2}{|c|}{$\begin{array}{l}(6.3 \pm 0.5) \times 10^{8} \frac{\mathrm{molec}}{\mathrm{cm}^{3}} \\
(2.9 \pm 0.2) \times 10^{8} \frac{\mathrm{molec}}{\mathrm{cm}^{3}}\end{array}$} & \multicolumn{2}{|c|}{$\begin{array}{l}(10.2 \pm 1.9) \times 10^{8} \frac{\mathrm{molec}}{\mathrm{cm}^{3}} \\
(2.6 \pm 0.6) \times 10^{8} \frac{\mathrm{molec}}{\mathrm{cm}^{3}}\end{array}$} & \multicolumn{2}{|c|}{$\begin{array}{l}(5.7 \pm 0.6) \times 10^{8} \frac{\mathrm{molec}}{\mathrm{cm}^{3}} \\
(7.0 \pm 1.2) \times 10^{8} \frac{\mathrm{molec}}{\mathrm{cm}^{3}}\end{array}$} & \multicolumn{2}{|c|}{$\begin{array}{l}(4.7 \pm 1.5) \times 10^{8} \frac{\mathrm{molec}}{\mathrm{cm}^{3}} \\
(3.3 \pm 1.3) \times 10^{8} \frac{\mathrm{molec}}{\mathrm{cm}^{3}}\end{array}$} \\
\hline
\end{tabular}

Table 9. Averaged mixing ratios for the parameters which constrain the box model simulations. The values are given for the four cases in Table 7 and 8 with their $1 \sigma$ variability.

\begin{tabular}{lrrrr}
\hline Species & case 1 & case 2 & case 3 & case 4 \\
\hline $\mathrm{CO}(\mathrm{ppbV})$ & $94 \pm 5$ & $122 \pm 13$ & $100 \pm 12$ & $101 \pm 7$ \\
Isoprene $(\mathrm{ppbV})$ & $0.7 \pm 0.2$ & $4.3 \pm 1.2$ & 0 & $0.2 \pm 0.2$ \\
$\mathrm{MVK}+\mathrm{MACR}(\mathrm{ppbV})$ & $0.2 \pm 0.1$ & $1.6 \pm 0.5$ & $0.03 \pm 0.02$ & $0.2 \pm 0.3$ \\
$\mathrm{O}_{3}(\mathrm{ppbV})$ & $14 \pm 0.1$ & $17 \pm 4$ & $29 \pm 5$ & $35 \pm 9$ \\
$\mathrm{NO}(\mathrm{pptV})$ & $65 \pm 57$ & $13 \pm 9$ & $10 \pm 3$ & $8 \pm 4$ \\
$\mathrm{H}_{2} \mathrm{O}(\mathrm{mmol} / \mathrm{mol})$ & $24 \pm 0.5$ & $23 \pm 2$ & $11 \pm 1$ & $9 \pm 2$ \\
$\mathrm{H}_{2} \mathrm{O}_{2}(\mathrm{ppbV})$ & $1.0 \pm 0.1$ & $2.2 \pm 1.8$ & $3.9 \pm 1.2$ & $2.3 \pm 1.6$ \\
$\mathrm{ROOH}(\mathrm{ppbV})$ & $0.5 \pm 0.2$ & $1.4 \pm 0.6$ & $1.0 \pm 0.2$ & $0.9 \pm 0.5$ \\
$\mathrm{HCHO}(\mathrm{ppbV})$ & $0.6 \pm 0.3$ & $1.2 \pm 0.4$ & $0.5 \pm 0.4$ & $0.4 \pm 0.5$ \\
$\mathrm{Acetone}(\mathrm{ppbV})$ & $0.6 \pm 0.1$ & $1.1 \pm 0.2$ & $0.7 \pm 0.2$ & $0.6 \pm 0.1$ \\
$\mathrm{Methanol}(\mathrm{ppbV})$ & $0.9 \pm 0.2$ & $3.2 \pm 0.4$ & $2.3 \pm 1.1$ & $2.5 \pm 0.5$ \\
$\left.\mathrm{~J}\left(\mathrm{O}^{1}{ }^{1} \mathrm{D}\right)\right)\left(10^{-5} \mathrm{~s}^{-1}\right)$ & $2.9 \pm 0.2$ & $2.5 \pm 1.0$ & $9.2 \pm 0.3$ & $3.4 \pm 1.1$ \\
$\mathrm{~J}\left(\mathrm{NO}_{2}\right)\left(10^{-4} s^{-1}\right)$ & $91 \pm 4$ & $82 \pm 26$ & $175 \pm 1$ & $111 \pm 27$ \\
\hline
\end{tabular}




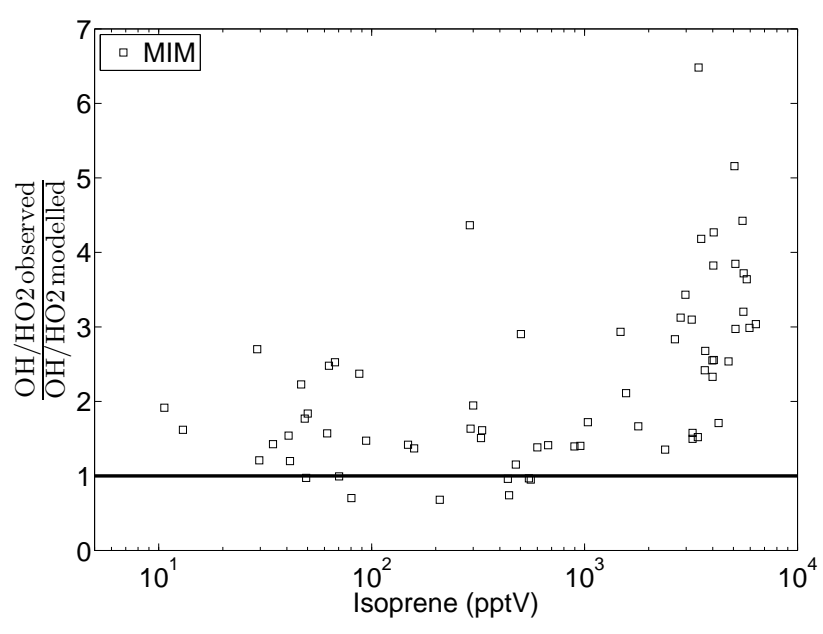

Fig. 15. Comparison of the ratio $\mathrm{OH} / \mathrm{HO}_{2}$ between observation and model as a function of isoprene.

The recycling reactions of $\mathrm{RO}_{2}+\mathrm{NO}$ are the dominant processes for $\mathrm{HO}_{2}$ production in the morning boundary layer over the forest (case 1), when NO concentrations are relatively high. When irradiation increases, photolysis of formaldehyde becomes an important source of the $\mathrm{HO}_{2}$ radical (case 2). In the free troposphere the main source of $\mathrm{HO}_{2}$ is the reaction of $\mathrm{OH}$ with carbon monoxide.

Recycling of $\mathrm{OH}$ by the reaction $\mathrm{NO}+\mathrm{HO}_{2}$ dominates the loss of $\mathrm{HO}_{2}$ when morning $\mathrm{NO}$ is high within the forest boundary layer, initially not leading to radical loss. For the remaining cases the reaction with peroxy radicals and the self reaction, producing peroxides, are the major loss terms for $\mathrm{HO}_{2}$. Since the photolysis of peroxides is slow to produce radicals, the production of peroxides effectively leads to removal of two radicals per reaction from the system.

Interconversion of $\mathrm{HO}_{2}$ and $\mathrm{OH}$ via reactions with e.g. $\mathrm{NO}, \mathrm{O}_{3}, \mathrm{CO}$ and VOC (Fig. 13) can be characterized by the chain length of the reactions cycling between these two radicals. The $\mathrm{HO}_{2} / \mathrm{OH}$ ratio in the forest boundary layer in the morning (case 1) shows a mean value of $127 \pm 34$ at mean NO mixing ratios of $(65 \pm 57) \mathrm{pptV}$. The value is comparable to results from Tan et al. (2001), who found $\mathrm{HO}_{2} / \mathrm{OH}$ ratios of $80-120$ for mean NO levels of $65.8 \mathrm{pptV}$ over deciduous forest in northern latitudes. Simulation by MECCA slightly overestimates the ratio with $\mathrm{HO}_{2} / \mathrm{OH}=$ $156 \pm 45$. For the forest boundary layer in the afternoon (case 2) values of $\mathrm{HO}_{2} / \mathrm{OH}=234 \pm 44$ were observed for mean NO mixing ratios of $(13 \pm 9) \mathrm{pptV}$. The model overestimates this ratio of $\mathrm{HO}_{2}$ to $\mathrm{OH}$ by a factor of $3.2 \pm 0.8$, OH being underestimated more severely than $\mathrm{HO}_{2}$ in the simulations. However, the correlation with the isoprene mixing ratio observed for $\mathrm{OH}$ and $\mathrm{HO}_{2}$ (Fig. 12) is not significant for the ratio (Fig. 15) since the effect of isoprene on $\mathrm{OH}$ and $\mathrm{HO}_{2}$ is similar for both radicals. The analysis of the different reactions relevant for the $\mathrm{HO}_{\mathrm{x}}$ budget (Tables 7,8 ) shows that isoprene and its peroxy radicals are the major compounds responsible for $\mathrm{HO}_{\mathrm{x}}$ loss $(\sim 50 \%)$ in the afternoon forest boundary layer. $\mathrm{OH}$ is directly removed by reaction with isoprene, producing the peroxy radical $\mathrm{ISO}_{2}$, which either removes $\mathrm{HO}_{2}$ from the system, forming the peroxide ISOOH $(60 \%)$, or produces $\mathrm{HO}_{2}$ and formaldehyde by reactions with $\mathrm{RO}_{2}$ or NO (40\%).

During the GABRIEL campaign Sinha et al. (2008) performed $\mathrm{OH}$ reactivity measurements within the canopy of the rainforest (about $35 \mathrm{~m}$ above the ground). 35\% of their measured total $\mathrm{OH}$ reactivity is due to reaction of $\mathrm{OH}$ with isoprene, MVK+MACR, acetone, acetaldehyde and methane, whereas $65 \%$ could not be explained by the measured species. They proposed that the missing fraction of the total reactivity is possibly due to unmeasured reactive compounds. For our studies this would lead to even larger discrepancies between the observation and the box model simulations. However our aircraft measurements and the $\mathrm{OH}$ reactivity measurements of Sinha et al. (2008) were made at different altitudes. Highly reactive unmeasured compounds, emitted from the rainforest, might only play an significant role inside the canopy and might be too short-lived to reach the sampling area of the aircraft above $300 \mathrm{~m}$.

\subsection{Recycling probability and missing source strength for $\mathrm{OH}$}

To determine the recycling strength of the chemical system, the recycling probability has been calculated. The $\mathrm{OH}$ recycling probability $r$ is defined as (Lelieveld et al., 2002):

$r=\frac{S}{P+S}$,

with $P$ and $S$ being the primary and secondary production, respectively. The primary production is considered to be only the reaction of $\mathrm{O}\left({ }^{1} \mathrm{D}\right)+\mathrm{H}_{2} \mathrm{O}$, whereas photolysis of peroxides and recycling reactions of $\mathrm{HO}_{2}$ are assumed to be secondary productions terms, as the reactants are oxidation products in the $\mathrm{OH}$ oxidation chain. The base simulation of MECCA yields $P=3.12 \times 10^{6}$ molec $^{-3} \mathrm{~s}^{-1}$ and $S=1.94 \times 10^{6} \mathrm{moleccm}^{-3} \mathrm{~s}^{-1}$ and therefore $r=$ 0.38 for boundary layer values over the forest in the afternoon (case 2). The total loss term $L$ in steady state simulations is equal to the total production term $G$ with $L=G=P+S=5.06 \times 10^{6}$ moleccm $^{-3} \mathrm{~s}^{-1}$. Calculations using measured higher $\mathrm{OH}$ and $\mathrm{HO}_{2}$ to constrain the box model, containing the same chemical mechanism, leads to $P=3.12 \times 10^{6}$ molec $^{-3} \mathrm{~s}^{-1}$ and $S=3.53 \times$ $10^{6} \mathrm{moleccm}^{-3} \mathrm{~s}^{-1}$. The total production term is therefore $G=6.65 \times 10^{6}$ moleccm $^{-3} \mathrm{~s}^{-1}$ compared to the total loss term of $L=56.64 \times 10^{6} \mathrm{moleccm}^{-3} \mathrm{~s}^{-1}$, calculated with MECCA constrained by the $\mathrm{HO}_{\mathrm{x}}$ observations. Thus, a production rate term of the order $S^{*}=5 \times$ $10^{7} \mathrm{molec}^{-3} \mathrm{~s}^{-1}$ is missing. Adding the missing term as secondary production would lead to a recycling probability 

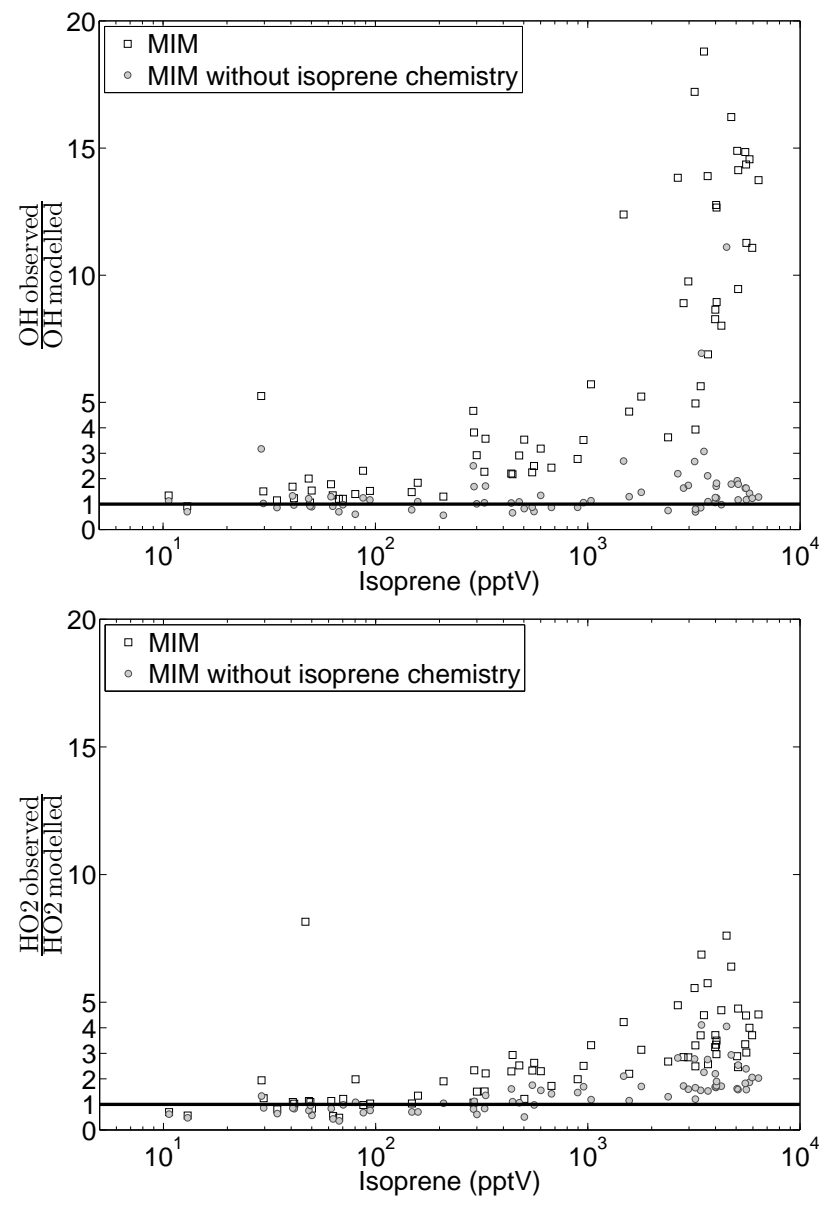

Fig. 16. Ratio of observed and modelled $\mathrm{OH}$ and $\mathrm{HO}_{2}$ concentrations as a function of isoprene and other conditions observed simultaneously with isoprene.

due to the observation of $r=0.94$. Considering that this value of $r$ is very high, it may be speculated that part of the missing $\mathrm{OH}$ formation is related to primary formation involving $\mathrm{O}_{3}$. Previously it has been indicated that reactions of $\mathrm{O}_{3}$ with reactive terpenes might be important (Tan et al., 2001; Di Carlo et al., 2004; Goldstein et al., 2004). Alternatively, $\mathrm{O}_{3}$ may react with reaction products in the isoprene degradation pathway, produce $\mathrm{OH}$ and reduce the discrepancy, which would moderate the $\mathrm{OH}$ recycling probability.

The missing term $S^{*}$ is comparable to the loss rate of $\mathrm{OH}$ through direct reaction with isoprene. By neglecting the entire isoprene chemistry in the box model MECCA, good agreement between simulations and $\mathrm{HO}_{\mathrm{x}}$ observations is obtained, independent of the isoprene concentrations that were observed (Fig. 16). This indicates that the reason for the model underestimations rather lies in the oxidation mechanism of isoprene than in missing direct sources. An observed to modelled ratio of $1.3 \pm 0.5$ for $\mathrm{OH}$ is found
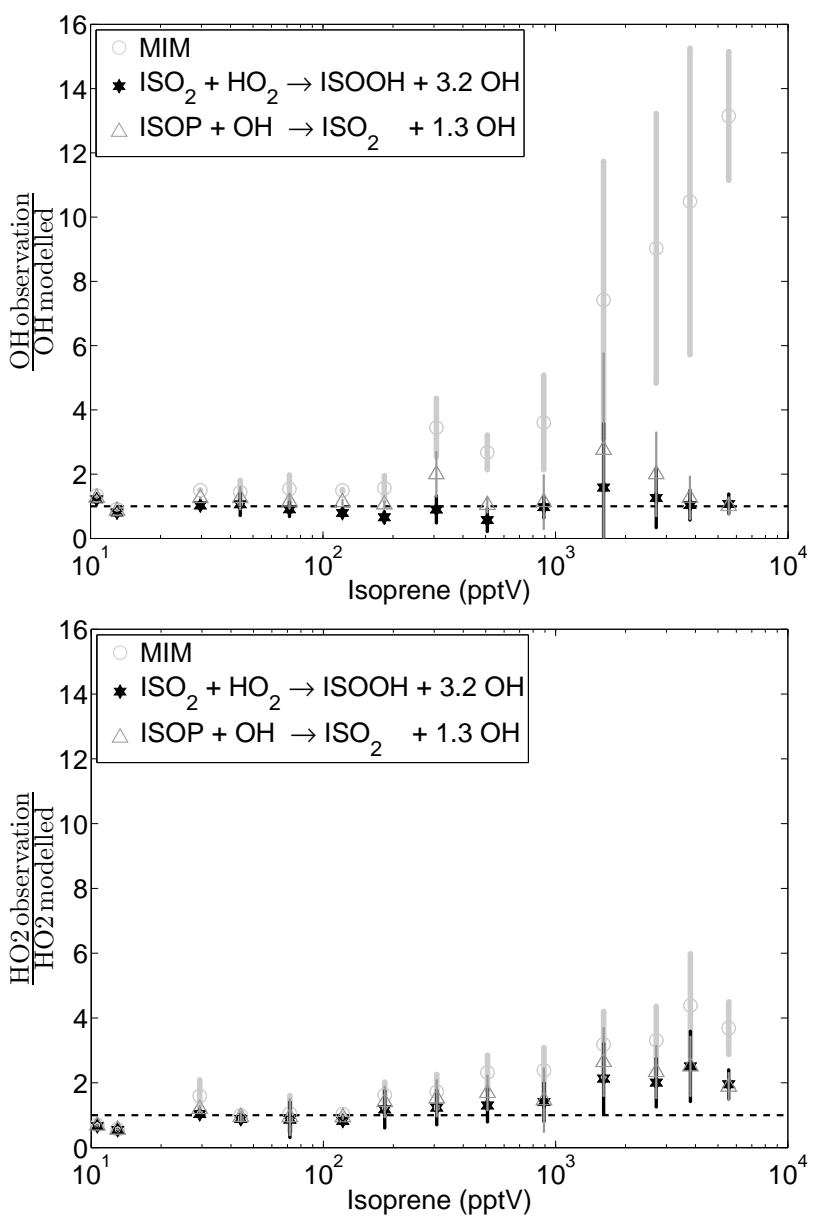

Fig. 17. Comparison between observation and a model run including the additional $\mathrm{HO}_{\mathrm{x}}$ reaction: $\mathrm{ISO}_{2}+\mathrm{HO}_{2} \rightarrow \mathrm{ISOOH}+$ $n \mathrm{OH}$ and ISOP $+\mathrm{OH} \rightarrow \mathrm{ISO}_{2}+m \mathrm{OH}$. Values are binned in isoprene mixing ratios ( $\mathrm{x}$ ) of $\Delta \ln x=0.5$.

for all measured isoprene mixing ratios. The situation for $\mathrm{HO}_{2}$ is somewhat different. For low isoprene $(<200 \mathrm{pptV})$ the model now tends to overestimate $\mathrm{HO}_{2}$, but is still well described within the uncertainty $(0.9 \pm 0.3)$. In contrast to $\mathrm{OH}$, the dependence on the isoprene concentration is still discernable, though small, possibly indicating an additional influence on $\mathrm{HO}_{2}$ by other trace gases also dependent on the time of day.

Butler et al. (2008) analysed the GABRIEL dataset using a global model. Analogous to the implementations of Reaction (R8) in our model, they introduced a modification of the reaction of the isoprene peroxy radical $\mathrm{ISO}_{2}$ with $\mathrm{HO}_{2}$ producing $n \cdot \mathrm{OH}$ in their reaction scheme:

$\mathrm{ISO}_{2}+\mathrm{HO}_{2} \longrightarrow \mathrm{ISOOH}+n \mathrm{OH}$. 
An optimum number of $n=2$ was derived to best reproduce the $\mathrm{OH}$ observations. For our constrained box model the best agreement between observation and simulation was found for $n=3.2$ (Fig. 17). A mean measured to modelled ratio of $1.0 \pm 0.3$ was obtained for $\mathrm{OH}$ and the dependence on isoprene disappeared.

Reaction (R11) should be understood as a proxy for additional recycling within the isoprene chemistry. The equivalent reaction:

$\mathrm{ISOP}+\mathrm{OH} \longrightarrow \mathrm{ISO}_{2}+m \mathrm{OH}$.

with best agreement for $m=1.3$ shows that regarding the initial step in the oxidation mechanism more $\mathrm{OH}$ has to be produced than destroyed. A mean value for the observed to model ratio of $1.4 \pm 0.5$ was calculated (Fig. 17). Additional sources of $\mathrm{OH}$, comparable and correlated to the isoprene sink are needed to describe the observations. Unknown $\mathrm{OH}$ recycling within the isoprene oxidation mechanism seems the most likely way to provide the additional $\mathrm{OH}$ source, leading to a much larger oxidation capacity of the atmosphere over the tropical rainforest.

\section{Follow up studies to the GABRIEL campaign}

During GABRIEL the first reported measured $\mathrm{HO}_{\mathrm{x}}$ concentrations over a tropical rainforest were found to be significantly higher than predicted by current models. Whereas studies performed in remote areas or distant from direct VOC emissions showed a rather good agreement (Whalley et al., 2010), studies close to biogenic VOC sources generally reported higher $\mathrm{OH}$ concentrations under low $\mathrm{NO}_{\mathrm{x}}$ conditions than expected.

Former measurements of $\mathrm{HO}_{\mathrm{x}}$ radicals over deciduous forests in the mid latitudes have shown significant underestimations of the observed $\mathrm{OH}$ concentration compared to box model simulations (Tan et al., 2001; Carslaw et al., 2001; Ren et al., 2008). Tan et al. (2001) found a deviation by a factor of $\sim 3$ for the $\mathrm{OH}$ radicals, particularly for low $\mathrm{NO}_{\mathrm{x}}$ and high isoprene conditions. Carslaw et al. (2001) also simulated 50\% less $\mathrm{OH}$ than measured at averaged isoprene levels of 2 pbbv. Analyses of Ren et al. (2008) showed, consistent with this study, a correlation of the deviations between simulations and observations with the isoprene concentrations. Although the values of model to measured $\mathrm{OH}$ ratio vary for the different measurement conditions, all box models show an underestimation of the observed $\mathrm{OH}$ concentrations, indicating a general inconsistency of the radical chemistry in box models for biogenic low $\mathrm{NO}_{\mathrm{x}}$ regions.

It is well known that the tropical rainforest are a major source of BVOCS, which up to now were predicted to suppress the oxidation capacity of the atmosphere. However, the unexpected results of the GABRIEL campaign have reflected the lack of knowledge in describing the chemical processes over these important regions and therefore have initiated worldwide research in this field. More $\mathrm{HO}_{\mathrm{x}}$ measurements in and over the tropical rainforest followed, like the OP3 and AMMA campaign in Borneo and West Africa, respectively (Hewitt et al., 2010; Commane et al., 2010). Both campaigns reported daily maximum $\mathrm{OH}$ concentrations up to $8.7 \times 10^{6} \mathrm{molecm}^{-3}$ and $0.6 \mathrm{pptV}$ on ground, respectively. Although higher NO concentrations were observed, the $\mathrm{OH}$ concentrations are comparable to those of GABRIEL $\left(\sim 0.5 \mathrm{pptV}\right.$ i.e. $6 \times 10^{6} \mathrm{moleccm}^{-3}$, Martinez et al., 2010). Unfortunately due to technical problems, the observed OH-concentrations over West Africa were rarely above the detection limit, so that a model-to-measurement comparison was not possible (Stone et al., 2010). However for a point-to-point comparison model simulations by Saunois et al. (2009) might indicate an underestimation by a factor of 2 , whereas Stone et al. (2010) conclude a possible overestimation of the model. The overestimation could be caused by the higher observed NO concentrations $(\sim 51 \mathrm{pptV}$, Stone et al., 2010 ), in contrast to the low NO regime of GABRIEL, where the largest deviations were found at $\mathrm{NO} \approx 13 \mathrm{pptV}$. However comparison of the Borneo data with the box model (CiTTyCAT) again showed an underestimation of the observed concentration by a factor of $\sim 3$, being in a $\mathrm{NO}$ regime of about $37 \mathrm{pptV}$ (Pugh et al., 2010a).

Measurements in the polluted Pearl River Delta, China, showed a good agreement with model calculations for high NO concentrations ( $>1 \mathrm{ppbv}$ ), whereas under high VOC and moderately low NO conditions $(<200 \mathrm{pptV})$ measured $\mathrm{OH}$ is 3 to 5 times higher than expected by our current understanding (Hofzumahaus et al., 2009). However, compared to the low NO concentrations during GABRIEL, where the reaction between $\mathrm{RO}_{2}+\mathrm{HO}_{2}$ are most dominant and might lead to unknown $\mathrm{OH}$ recycling, the situation in the Pearl River Delta is more determined by the competing reaction of $\mathrm{RO}_{2}+\mathrm{NO}$. Therefore Hofzumahaus et al. (2009), similar to Tan et al. (2001), proposed another pathway of additional $\mathrm{OH}$ recycling via $\mathrm{RO}_{2}+\mathrm{X} \longrightarrow \mathrm{HO}_{2}$ and $\mathrm{HO}_{2}+\mathrm{X} \longrightarrow \mathrm{OH}$ to gain sufficient $\mathrm{OH}$ production under moderately low NO conditions.

Containing the traditional chemistry different box models have been tested to find an explanation for the high $\mathrm{HO}_{\mathrm{x}}$ observations over the tropical rainforest. Taraborrelli et al. (2009) presented the improved version MIM2 of the MIM mechanism, derived as a reduction from the MCM scheme. The MIM2 model scheme has been applied for the GABRIEL conditions with low NO, as well as with medium and high NO concentrations. An increase of up to $15 \%$ in the calculated $\mathrm{OH}$ was feasible, but still the measurements of GABRIEL could not be explained. Archibald et al. (2009) applied eight different complex isoprene mechanisms by using high isoprene emissions rates (up to $6.4 \mathrm{mg} \mathrm{m}^{-2} \mathrm{~h}^{-1}$, corresponding to about $1.6 \times$ $\left.10^{12} \mathrm{molec}^{-2} \mathrm{~s}^{-1}\right)$, representative for tropical rainforest 
conditions. Each model, independent from the complexity of the chemical mechanisms, simulated very low $\mathrm{OH}$ concentrations under low $\mathrm{NO}_{\mathrm{x}}$ conditions $(\mathrm{OH}$ daytime average of $10^{5} \mathrm{molec}^{-3}$ ), confirming that all current isoprene mechanisms are unable to match the observed $\mathrm{HO}_{\mathrm{x}}$ concentrations. Model agreement could only be reached by including an additional $\mathrm{OH}$ source in the order of $2.0 \times 10^{7} \mathrm{moleccm}^{-3} \mathrm{~s}^{-1}$, dependent on the light controlled correction factor of the isoprene emissions, which is consistent with the GABRIEL results.

New possible reaction pathways for $\mathrm{OH}$ recycling within the isoprene oxidation mechanisms have further been investigated by quantum chemical calculations and have partly been tested by laboratory studies. A promising approach is the competing unimolecular reaction of certain $\mathrm{RO}_{2}$ radicals via $\mathrm{H}$-shift, which is predicted to lead to $\mathrm{OH}$ and/or $\mathrm{HO}_{2}$ formation. For these reactions Peeters et al. (2009) calculated a yield of about $0.7 \mathrm{HO}_{2}$ and $0.03 \mathrm{OH}$ radicals per isoprene oxidized, whereas Da Silva et al. (2010) suggest an yield up to $0.07 \mathrm{OH}$, both calculations done for pristine tropical rainforest conditions. Only theoretically proposed and not confirmed by laboratory measurements, this pathway alone is still not sufficient to describe the GABRIEL measurements. Nevertheless, possible photo labile coproducts, e.g. hydroperoxyaldehydes, with a unity yield become an additional $\mathrm{OH}$ source and might provide an explanation for the high observed $\mathrm{OH}$ concentration over the tropical rainforest. Another not yet fully incorporated mechanism for $\mathrm{OH}$ recycling is the formation of epoxides, which has been predicted by quantum chemical calculations and also found in chamber experiments (Paulot et al., 2009). Epoxides are of particular interest because of their potential to form SOA under low $\mathrm{NO}_{\mathrm{x}}$ conditions, which helps to resolve the open question of aerosol formation over the tropical rainforest (Kleindienst et al., 2009; Martin et al., 2010).

Implementation of the new proposed chemical mechanisms in box model simulations for tropical rainforest conditions was done by Archibald et al. (2010). Different scenarios were tested, showing the largest enhancement for modelled $\mathrm{OH}$ concentrations by including the discussed recycling reactions via $\mathrm{RO}_{2}+\mathrm{HO}_{2}$, epoxide formation, unimolecular reactions of the $\mathrm{RO}_{2}$ and photolysis of intermediates products. Applying the rate constants in their upper limits lead to 3.2 times more $\mathrm{OH}$ than the MCM scheme, which is consistent to the model results of this study. Within $30 \%$ the LIM0 (Leuven Isoprene Mechanism, Peeters et al., 2009) could explain the observed $\mathrm{HO}_{\mathrm{x}}$ concentrations during GABRIEL applied in global CTM calculations by Stavrakou et al. (2010). The scheme is characterised by fast elimination of $\mathrm{O}_{2}$ from the hydroperoxy radicals, the 1,5- and 1,6- $\mathrm{H}$-shift leading to $\mathrm{OH}$ and $\mathrm{HO}_{2}$ formation, respectively, and a very fast photo dissociation of the hydroperoxy aldehydes producing additional $\mathrm{OH}$ and $\mathrm{HO}_{2}$ radicals.
Beside the discussion of additional new chemical reactions and schemes to regenerate $\mathrm{OH}$, the effect of simple segregation of air masses (Krol et al., 2000; Karl et al., 2007; Dlugi et al., 2010) and deposition of $\mathrm{OH}$ reactants (Pugh et al., 2010a) has been investigated. Segregation, originating from incomplete mixing between air enriched with VOC and air enriched with $\mathrm{OH}$ can lead to an apparent reduction of the reaction constants. Studies comparing box model with LES simulations by Krol et al. (2000) show an apparent reduction of the RH-OH reaction rate by $30 \%$. Calculation of segregation over the Amazon rainforest during AMAZE-08, using water vapour as a proxy for unmeasured $\mathrm{OH}$ concentrations, showed a decrease of $k(\mathrm{OH}+\mathrm{ISOP})$ up to $(39 \pm 7) \%$ in the 800 -m-deep cloud layer (Karl et al., 2007), leading to higher simulated $\mathrm{OH}$ concentrations. Dlugi et al. (2010) calculated the intensity of segregation from highly time resolved trace gas measurements, including $\mathrm{OH}$ and isoprene, during the ECHO campaign in a deciduous forest in mid latitudes (Germany). For ECHO the authors demonstrated that the effective $\mathrm{OH}$ isoprene reaction rate is reduced by segregation by $15 \%$. A similar segregation intensity of $15 \%$ was found during OP3 by Pugh et al. (2010b), using simulated $\mathrm{OH}$ concentrations from a box model and measured isoprene concentrations. All studies show that segregation contributes to an apparent reduction of the $\mathrm{RH}-\mathrm{OH}$ reaction rate but cannot explain the magnitude of the discrepancy alone.

For ground based observations an increase of the deposition rates for $\mathrm{OH}$ reactants, like MACR and MVK, can help to to explain the measurement of the OP3 campaign in Borneo (Pugh et al., 2010a). By using a deposition rate of $v_{d}(\mathrm{MACR}+\mathrm{MVK})=2.5 \mathrm{cms}^{-1}$ and reducing the reaction rate constant $k$ (isoprene/monoterpenes $+\mathrm{OH}$ ) by $50 \%$, the $\mathrm{OH}$-observations over the Borneo rainforest could be reproduced.

Currently several global models use a reduced isoprene emission rates of of $220-350 \mathrm{TgCyr}^{-1}$ (Brasseur et al., 1998; Kuhlmann et al., 2003), which is much lower than observations have shown $\left(500 \mathrm{TgCyr}^{-1}\right.$, Guenther et al., 1995). The high $\mathrm{OH}$ concentrations, as observed during GABRIEL, reduce the lifetime of isoprene significantly, and might close the inconsistency in the isoprene flux.

The initial work done during GABRIEL, which is confirmed by measurements of other groups, indicate that in low NO environments the oxidation of biogenic VOC leads to more recycling and regeneration of $\mathrm{OH}$ then assumed until now.

\section{Conclusions}

Higher $\mathrm{HO}_{\mathrm{x}}$ concentrations over the tropical rainforest during the GABRIEL campaign were observed than predicted by the box model MECCA constrained by measurements. Observations and simulations agree fairly 
well for the free troposphere, whereas maximum deviations were found for low altitudes $(<1 \mathrm{~km})$ in the afternoon with mean discrepancy factors of $12.2 \pm 3.5$ and $4.1 \pm 1.4$ for $\mathrm{OH}$ and $\mathrm{HO}_{2}$, respectively. These discrepancies are strongly correlated to isoprene emitted by the rainforest. However, the $\mathrm{OH} / \mathrm{HO}_{2}$ ratio does not show a significant dependence on isoprene, as $\mathrm{OH}$ and $\mathrm{HO}_{2}$ are similarly influenced by isoprene. Simulations with the more detailed isoprene mechanism of the MCM leads to similar results as the MIM chemical reaction scheme, indicating that the original objective of using a condensed mechanism to reproduce the results of the MCM is still met.

In the simulations with MECCA radical loss from the system via removal of $\mathrm{RO}_{2}$ producing organic peroxides, appears to be about $50 \%$ for air in the afternoon boundary layer. Sensitivity studies eliminating the production of organic peroxides increase the $\mathrm{HO}_{2}$ and $\mathrm{OH}$ concentrations, but not sufficiently to achieve agreement with the observations.

Enhancement of photolysis frequencies of organic peroxides by unlikely factors of $10^{3}$ do not provide a sufficient source for $\mathrm{HO}_{\mathrm{x}}$. Constraining the model to measured $\mathrm{HO}_{2}$ enhances $\mathrm{OH}$, but is also insufficient to match observations. Therefore, an additional production channel of $\mathrm{OH}$ is needed to explain the $\mathrm{OH}$ observed over the rainforest. Modification of the chemistry scheme of MECCA could not sufficiently enhance the the simulated $\mathrm{HO}_{\mathrm{x}}$ concentration, either by recycling of $\mathrm{OH}$ through reaction of peroxy radicals with $\mathrm{HO}_{2}$ or through infrared photolysis of peroxy radicals, or by combining the two.

Constraining the $\mathrm{HO}_{\mathrm{x}}$ concentration in the simulations led to an overestimation of $\mathrm{HCHO}$ and peroxides, pointing to the importance of a large $\mathrm{RO}_{2}$ production within the isoprene oxidation scheme (Stickler et al., 2007). Therefore alternative reaction pathways, producing $\mathrm{OH}$ and simultaneously reducing peroxide formation, is still a likely way, but must have a stronger effect (either combined or on their own) than the reactions tested in this study.

The major $\mathrm{OH}$ and $\mathrm{HO}_{2}$ sources over the rainforest $(<1 \mathrm{~km})$ in the afternoon are the reaction of $\mathrm{O}\left({ }^{1} \mathrm{D}\right)+$ $\mathrm{H}_{2} \mathrm{O}$ and the photolysis of $\mathrm{HCHO}$. When available in the atmosphere, isoprene and its oxidation products strongly influence the $\mathrm{OH}$ chemistry leading to a loss rate of $\mathrm{OH}$ in the model comparable to the primary production rate. A recycling probability of $r=0.38$ follows from the standard simulation, whereas a value of up to $r=$ 0.94 is needed to explain the observations. An $\mathrm{OH}$ source stronger than the loss rate owing to ISOP $+\mathrm{OH}$ is evidently missing in the chemical mechanism based on current understanding $\left(S^{*}=5 \times 10^{7}\right.$ molec $\left.^{-3} \mathrm{~s}^{-1}\right)$. By neglecting the isoprene chemistry in MECCA, the underestimation of the $\mathrm{HO}_{\mathrm{x}}$ simulations disappears. This leads to the hypothesis that the recycling of $\mathrm{OH}$, mainly in the isoprene oxidation mechanism, is more efficient than predicted by the current reaction schemes. The additional recycling reaction via $\mathrm{ISOP}+\mathrm{OH} \rightarrow \mathrm{ISO}_{2}+m \cdot \mathrm{OH}$ with $m=1.3$ improves the agreement with the $\mathrm{OH}$ observations, and further investigations to unravel the detailed chemical mechanisms are recommended.

Following the GABRIEL campaign several approaches to understand the tropospheric chemistry over the tropical rainforest have been made by different research groups. Comparable $\mathrm{OH}$ concentrations were found over the tropical rainforest of West Africa and Borneo. Theoretical quantum chemical calculations as well as laboratory measurements have been performed to propose alternative reaction pathways inside the isoprene oxidation scheme. Box model simulations including these reactions often failed to explain the GABRIEL observations. Implying a high photo dissociation rate of the predicted intermediates the LIMO mechanism was able to reproduce the GABRIEL data within $30 \%$ in global CTM calculations (Stavrakou et al., 2010). Promising concepts have been proposed but still have to be confirmed by laboratory and field measurements. Explaining the high unexpected observed $\mathrm{OH}$ concentrations over the tropical rainforest remains a major task in atmospheric science.

\section{Supplementary material related to this article is available online at: http://www.atmos-chem-phys.net/10/9705/2010/ acp-10-9705-2010-supplement.pdf.}

Acknowledgements. The authors are grateful to the whole GABRIEL team, ENVISCOPE GmbH (Frankfurt, Germany) and GFD (Hohn, Germany) for their support, essential for the successful realisation of the GABRIEL campaign. We appreciate the good cooperation with the Suriname Meteorological Service (MDS) and the Anton de Kom University of Suriname (both in Paramaribo, Suriname).

The service charges for this open access publication have been covered by the Max Planck Society.

Edited by: R. Cohen

\section{References}

Archibald, A. T., Jenkin, M. E., Shallcross, D.E.: An isoprene mechanism intercomparison Atmos. Environ., in press, 1352-2310, doi:10.1016/j.atmosenv.2009.09.016, 2009.

Archibald, A. T., Cooke, M. C., Utembe, S. R., Shallcross, D. E., Derwent, R. G., Jenkin, M. E.: Impacts of mechanistic changes on $\mathrm{HO}_{\mathrm{x}}$ formation and recycling in the oxidation of isoprene, Atmos. Chem. Phys., 10, 8097-8118, doi:10.5194/acp-10-8097-2010, 2010.

Atkinson, R., Baulch, D. L., Cox, R. A., Crowley, J. N., Hampson, R. F., Hynes, R. G., Jenkin, M. E., Rossi, M. J., Troe, J.: Evaluated kinetic and photochemical data for atmospheric chemistry: Volume $\mathrm{I}$ - gas phase reactions of $\mathrm{O}_{\mathrm{x}}, \mathrm{HO}_{\mathrm{x}}, \mathrm{NO}_{\mathrm{x}}$ 
and $\mathrm{SO}_{\mathrm{x}}$ species, Atmos. Chem. Phys., 4, 1461-1738, 2004, http://www.atmos-chem-phys.net/4/1461/2004/.

Atkinson, R., Baulch, D. L., Cox, R. A., Crowley, J. N., Hampson, R. F., Hynes, R. G., Jenkin, M. E., Rossi, M. J., Troe, J., and IUPAC Subcommittee: Evaluated kinetic and photochemical data for atmospheric chemistry: Volume II gas phase reactions of organic species, Atmos. Chem. Phys., 6, 3625-4055, doi:10.5194/acp-6-3625-2006, 2006.

Brasseur, G. P., Hauglustaine, D. A., Walters, S., Rasch, P. J., Müller, J.-F., Granier, C., and Tie, X. X.: MOZART, a global chemical transport model for ozone and related chemical tracers, 1. Model description, J. Geophys. Res., 103(D21), 28265-28290, 1998.

Butler, T. M., Taraborrelli, D., Brühl, C., Fischer, H., Harder, H., Martinez, M., Williams, J., Lawrence, M. G., and Lelieveld, J.: Improved simulation of isoprene oxidation chemistry with the ECHAM5/MESSy chemistry-climate model: lessons from the GABRIEL airborne field campaign, Atmos. Chem. Phys., 8, 4529-4546, doi:10.5194/acp-8-4529-2008, 2008.

Carslaw, N., Creasey, D. J., Harrison, D., Heard, D. E., Hunter, M. C. , Jacobs, P. J., Jenkin, M.E., Lee, J.D., Lewis, A. C. , Pilling, M.J., Saunders, S. M., and Seakins, P.W.: $\mathrm{OH}$ and $\mathrm{HO}_{2}$ radical chemistry in a forested region of north-western Greece, Atmos. Environ., 35, 4725-4737, 2001.

Commane, R., Floquet, C. F. A., Ingham, T., Stone, D., Evans, M. J., Heard, D. E.: Observations of $\mathrm{OH}$ and $\mathrm{HO}_{2}$ radicals over West Africa, Atmos. Chem. Phys., 10, 8783-8801, doi:10.5194/acp-10-8783-2010, 2010.

Crawford, J., Davis, D., Olson, J., et al.: Assessment of upper tropospheric $\mathrm{HO}_{\mathrm{x}}$ source over the tropical Pacific based on NASA GTE/PEM data: Net affect on $\mathrm{HO}_{\mathrm{x}}$ and other photochemical parameters, J. Geophys. Res., 104, 16, 255-16, 273, 1999.

Da Silva, G., Graham, C., and Wang, A.-F.: Unimolecular $\beta$-Hydroxyperoxy Radical Decomposition with $\mathrm{OH}$ Recycling in the Photochemical Oxidation of Isoprene, Environ. Sci. Technol., 44, 250-256, 2010.

Di Carlo, P., Brune, W. H., Martinez, M., Harder, H., Lesher, R., Ren, X. Thornberry, T., Carroll, M. A., Young, V., Shepson, P. B., Riemer, D., Apel, E., and Campbell, C.: Missing OH Reactivity in a Forest: Evidence for Unknown Reactive Biogenic VOCs, Science, 304, 722-725, 2004.

Dillon, T. J. and Crowley, J. N.: Direct detection of $\mathrm{OH}$ formation in the reactions of $\mathrm{HO}_{2}$ with $\mathrm{CH}_{3} \mathrm{C}(\mathrm{O}) \mathrm{O}_{2}$ and other substituted peroxy radicals, Atmos. Chem. Phys., 8, 4877-4889, doi:10.5194/acp-8-4877-2008, 2008.

Dlugi, R., Berger, M., Zelger, M., Hofzumahaus, A., Siese, M., Holland, F., Wisthaler, A., Grabmer, W., Hansel, A., Koppmann, R., Kramm, G., Mllmann-Coers, M., and Knaps, A.: Turbulent exchange and segregation of HOx radicals and volatile organic compounds above a deciduous forest, Atmos. Chem. Phys., 10, 6215-6235, doi:10.5194/acp-10-6215-2010, 2010.

Eerdekens, G., Ganzeveld, L., Vilà-Guerau de Arellano, J., Klüpfel, T., Sinha, V., Yassaa, N., Williams, J., Harder, H., Kubistin, D., Martinez, M., and Lelieveld, J.: Flux estimates of isoprene, methanol and acetone from airborne PTR-MS measurements over the tropical rainforest during the GABRIEL 2005 campaign, Atmos. Chem. Phys., 9, 4207-4227, doi:10.5194/acp-9-4207-2009, 2009.
Eisele, F. L., Mount, G. H., Fehsenfeld, F. C., Harder, J., Marovich, E., Parrish, D. D., Roberts, J., and Trainer, M.: Intercomparison of tropospheric $\mathrm{OH}$ and ancillary trace gas measurements at Fritz Peak Observatory, Colorado, J. Geophys. Res., 99, 18, 605-626, 1994.

Fehsenfeld, F., Calvert, J., Fall, R., Goldan, P., Guenther, A. B., Hewitt, C. N., Lamb, B., Liu, S., Trainer, M., Westberg, H., and Zimmermann, P.: Emissions of volatile organic compounds from vegetation and the implications for atmospheric chemistry, Global Biogeochem. Cy., 6, 389-430, 1992.

Frost, G. J., Ellison, G. B., and Vaida, V.: Organic Peroxyl Radical Photolysis in the Near-Infrared: Effects on Tropospheric Chemistry J. Phys. Chem. A, 103, 10169-10178, 1999.

Fuentes, J. D., Lerdau, M., Atkinson, R., et al.: Biogenic hydrocarbons in the atmospheric boundary layer: A review, B. Am. Meteorol. Soc., 81(7),1537-1575, 2000.

Fuchs, H., Brauers, T., Dorn, H.-P., Harder, H., Häseler, R., Hofzumahaus, A., Holland, F., Kanaya, Y., Kajii, Y., Kubistin, D., Lou, S., Martinez, M., Miyamoto, K., Nishida, S., Rudolf, M., Schlosser, E., Wahner, A., Yoshino, A., and Schurath, U.: Technical Note: Formal blind intercomparison of $\mathrm{HO}_{2}$ measurements in the atmosphere simulation chamber SAPHIR during the HOxComp campaign, Atmos. Chem. Phys. Discuss., 10, 21189-21235, doi:10.5194/acpd-10-21189-2010, 2010.

Ganzeveld, L., Eerdekens, G., Feig, G., Fischer, H., Harder, H., Königstedt, R., Kubistin, D., Martinez, M., Meixner, F. X., Scheeren, H. A., Sinha, V., Taraborrelli, D., Williams, J., Vil-Guerau de Arellano, J., and Lelieveld, J.: Surface and boundary layer exchanges of volatile organic compounds, nitrogen oxides and ozone during the GABRIEL campaign, Atmos. Chem. Phys., 8, 6223-6243, doi:10.5194/acp-8-6223-2008, 2008.

Gierczak, T., Burkholder, J. B., Talukdar, R. K., Mellouki, A., Barone, S. B., and Ravishankara, A. R.: Atmospheric fate of methyl vinyl ketone and methacrolein, J. Photoch. Photobio. A, 110, 1-10, 1997.

Goldstein, A. H., McKay, M., Kurpius, M. R., Schade, G. W., Lee, A., Holzinger, R., Rasmussen, R. A.: Forest thinning experiment confirms ozone deposition to forest canopy is dominated by reaction with biogenic VOCs, Geophys. Res. Lett., 31, L22106, doi:10.1029/2004GL021259, 2004.

Granier, C., Pétron, G., Müller, J.-F., and Brasseur, G.: The impact of natural and anthropogenic hydrocarbons on the tropospheric budget of carbon monoxide, Atmos. Environ., 34, 5255-5270, 2000.

Guenther, A. B., Hewitt, G. N., Erickson, D., et al.: A global model of natural volatile organic compound emissions, J. Geophys. Res., 100(D5), 8873-8892, 1995.

Hasson, A. S., Tyndall, G. S., and Orlando, J. J.: A product yield study of the reaction of $\mathrm{HO} 2$ radicals with Ethyl Peroxy $\left(\mathrm{C}_{2} \mathrm{H}_{5} \mathrm{O}_{2}\right)$, Acetyl Peroxy $\left(\mathrm{CH}_{3} \mathrm{C}(\mathrm{O}) \mathrm{O}_{2}\right)$, and Acetonyl Peroxy $\left(\mathrm{CH}_{3} \mathrm{C}(\mathrm{O}) \mathrm{CH}_{2} \mathrm{O}_{2}\right)$ Radicals, J.Phys. Chem. A, 108, 5979-5989, 2004.

Heard, D. E. and Pilling, M. J.: Measurement of $\mathrm{OH}$ and $\mathrm{HO}_{2}$ in the Troposphere, Chem. Rev., 103, 5163-5198, 2003.

Hewitt, C. N., Lee, J. D., MacKenzie, A. R., Barkley, M. P., Carslaw, N., Carver, G. D., Chappell, N. A., Coe, H., Collier, C., Commane, R., Davies, F., Davison, B., DiCarlo, P., Di Marco, C. F., Dorsey, J. R., Edwards, P. M., Evans, M. J., 
Fowler, D., Furneaux, K. L., Gallagher, M., Guenther, A., Heard, D. E., Helfter, C., Hopkins, J., Ingham, T., Irwin, M., Jones, C., Karunaharan, A., Langford, B., Lewis, A. C., Lim, S. F., MacDonald, S. M., Mahajan, A. S., Malpass, S., McFiggans, G., Mills, G., Misztal, P., Moller, S., Monks, P. S., Nemitz, E., Nicolas-Perea, V., Oetjen, H., Oram, D. E., Palmer, P. I., Phillips, G. J., Pike, R., Plane, J. M. C., Pugh, T., Pyle, J. A., Reeves, C. E., Robinson, N. H., Stewart, D., Stone, D., Whalley, L. K., and Yin, X.: Overview: oxidant and particle photochemical processes above a south-east Asian tropical rainforest (the OP3 project): introduction, rationale, location characteristics and tools, Atmos. Chem. Phys., 10, 169-199, doi:10.5194/acp-10-169-2010, 2010.

Hofzumahaus, A., Rohrer, F., Lu, K., Bohn, B., Brauers, T., Chang, C., Fuchs, H., Holland, F., Kita, K., Kondo, Y., Li, X., Lou, S., Shao, M., Zeng, L., Wahner, A., and Zhang Y.: Amplified Trace Gas Removal in the Troposphere, Science, 324, 1702-1704, 2009.

Jackson, A. V. and Hewitt, C. N.: Atmosphere Hydrogen Peroxide and Organic Hydorperoxides: A Review, Critical Reviews in Environmental Science and Technolology, 29(2), 175-228, 1999.

Jenkin, M. E. and Hayman, G. D.: Kinetics of Reactions of Primary, Secondary and Tertiary $\beta$-Hydroxy Peroxyl Radicals, Application to Isoprene Degradation, J. Chem. Soc. Faraday Trans., 91(13), 1911-1922, 1995.

Jenkin, M. E., Saunders, S. M., and Pilling, M. J.: The tropospheric degradation of volatile organic compounds: a protocol for mechanism development, Atmos. Environ. 31, 81-104, 1997.

Jenkin, M. E., Hurley, M. D., and Wallington, T. J.: Investigation of the radical product channel of the $\mathrm{CH}_{3} \mathrm{COO}_{2}+\mathrm{HO}_{2}$ reaction in the gas phase, Phys. Chem. Chem. Phys. 9, 3149-3162, 2007.

Jöckel, P., Tost, H., Pozzer, A., Brühl, C., Buchholz, J., Ganzeveld, L., Hoor, P., Kerkweg, A., Lawrence, M. G., Sander, R., Steil, B., Stiller, G., Tanarhte, M., Taraborrelli, D., van Aardenne, J., and Lelieveld, J.: The atmospheric chemistry general circulation model ECHAM5/MESSy1: consistent simulation of ozone from the surface to the mesosphere, Atmos. Chem. Phys., 6, 5067-5104, doi:10.5194/acp-6-5067-2006, 2006.

Karl, T., Guenther, A., Yokelson, R. J., Greenberg, J., Potosnak, M., Blake, D. R., Artaxo, P.: The tropical forest and fire emissions experiment: Emission, chemistry and transport of biogenic volatile organic compounds in the lower atmosphere over Amazonia, J. Geophys. Res., 112, D18302, doi:10.1029/2007JD008539, 2007.

Kesselmeier, J. and Staudt, M.: Biogenic volatile organic compounds (VOC): An overview on emission, physiology and ecology, J. Atmos. Chem., 33, 23-88, 1999.

Kleindienst, T. E., Lewandowski, M., Offenberg, J. H., Jaoui, M., and Edney, E. O.: The formation of secondary organic aerosol from the isoprene $+\mathrm{OH}$ reaction in the absence of $\mathrm{NO}_{\mathrm{x}}$, Atmos. Chem. Phys., 9, 6541-6558, doi:10.5194/acp-9-6541-2009, 2009.

Krol, M. C., Molemaker, M. J., and Vilà Guerau de Arellano, J.: Effects of turbulence and heterogeneous emissions on photochemically active species in the convective boundary layer, J. Geophys. Res., 105(D5), 6871-6884, 2000.

Von Kuhlmann, R., Lawrence, M. G., and Crutzen, P. J.: A model for studies of tropospheric ozone and nonmethane hydrocarbons: Model descriptions and ozone results, J. Geophys. Res., 108(D9),
4294 pp., 2003.

von Kuhlmann, R., Lawrence, M. G., Pöschl, U., and Crutzen, P. J.: Sensitivities in global scale modeling of isoprene, Atmos. Chem. Phys., 4, 1-17, doi:10.5194/acp-4-1-2004, 2004.

Kuhn, U., Andreae, M. O., Ammann, C., Araújo, A. C., Brancaleoni, E., Ciccioli, P., Dindorf, T., Frattoni, M., Gatti, L. V., Ganzeveld, L., Kruijt, B., Lelieveld, J., Lloyd, J., Meixner, F. X., Nobre, A. D., Pöschl, U., Spirig, C., Stefani, P., Thielmann, A., Valentini, R., and Kesselmeier, J.: Isoprene and monoterpene fluxes from Central Amazonian rainforest inferred from tower-based and airborne measurements, and implications on the atmospheric chemistry and the local carbon budget, Atmos. Chem. Phys., 7, 2855-2879, doi:10.5194/acp-7-2855-2007, 2007.

Lelieveld, J., Peters, V., Dentener, F. J., and Krol, M.: Stability of tropospheric hydroxyl chemistry, J. Geophys. Res. 107, 4715 pp., doi:10.1029/2002JD002272, 2002.

Lelieveld, J., Butler, T. M., Crowley, J., Dillon, T., Fischer, H., Ganzeveld, L., Harder, H., Lawrence, M. G., Martinez, M., Taraborrelli, D., and Williams, J.: Atmospheric oxidation capacity sustained by a tropical forest, Nature, 452, 737-740, 2008.

Levy II, H.: Normal atmosphere: Large radical and formaldehyde concentrations predicted, Science, 173, 141-143, 1971.

Logan, J. A., Prather, M. J., Wofsy, S. C., and McElroy, M. B.: Tropospheric chemistry: A global perspective, J. Geophys. Res., 86, 7210-7254, 1981.

Madronich, S. and Flocke, S.: The role of solar radiation in atmospheric chemistry, in: Handbook of Environmental Chemistry, edited by: Boule, P., 1-26, Springer, New York, USA, 1998.

Martin, S. T., Andreae, M. O., Artaxo, P., Baumgardner, D., Chen, Q., Goldstein, A. H., Guenther, A., Heald, C. L., Mayol-Bracero, O. L., McMurry, P. H., Pauliquevis, T., Pöschl, U., Prather, K. A., Roberts, G. C., Saleska, S. R., Silva Dias, M. A., Spracklen, D. V., Swietlicki, E., and Trebs, I.: Sources and properties of amazonian sources and properties of amazonian aerosol particles, Rev. Geophys., 48, RG2002, 42 pp., 2010.

Martinez, M., Harder, H., Kubistin, D., Rudolf, M., Bozem, H., Eerdekens, G., Fischer, H., Klüpfel, T., Gurk, C., Königsstedt, R., Parchatka, U., Schiller, C. L., Stickler, A., Williams, J., and Lelieveld, J.: Hydroxyl radicals in the tropical troposphere over the Suriname rainforest: airborne measurements, Atmos. Chem. Phys., 10, 3759-3773, doi:10.5194/acp-10-3759-2010, 2010.

Paulot, F., Crounse, J. D., Kjaergaard, H. G., Kürten, A., Clair, J. M. St., Seinfeld, J. H., and Wennberg, P. O.: Unexpected Epoxide Formation in the Gas-Phase Photooxidation of Isoprene, Science, 325(5941), 730-733, 2009.

Paulson, S. E., Flagan, R. C., and Seinfeld, J. H.: Atmospheric photo-oxidation of isoprene: part I: the hydroxyl radical and ground state atomic oxygen reactions, Int. J. Chem. Kinet., 24, 79-101, 1992.

Peeters, J., Nguyenz, T. L., and Vereecken, L.: $\mathrm{HO}_{\mathrm{x}}$ radical regeneration in the oxidation of isoprene, Phys. Chem. Chem. Phys., 11, 5935-5939, 2009.

Pinho, P. G., Pio, C. A., and Jenkin, M. E.: Evaluation of isoprene degradation in the detailed tropospheric chemical mechanism, MCM v3, using environmental chamber data, Atmos. Environ., 39, 1303-1322, 2005. 
Pöschl, U., Von Kuhlmann, R., Poisson, N., and Crutzen, P. J.: Development and intercomparison of condensed isoprene oxidation mechanisms for global atmospheric modeling, J. Atmos. Chem., 37, 29-52, 2000.

Poisson, N., Kanakidou, M., and Crutzen, P. J.: Impact of Non-Methane Hydrocarbons on Tropospheric Chemistry and the Oxidizing Power of the Gobal Troposphere: 3-Dimensional Modelling Results, J. Atmos. Chem., 36, 157-230, 2000.

Pugh, T. A. M., MacKenzie, A. R., Hewitt, C. N., Langford, B., Edwards, P. M., Furneaux, K. L., Heard, D. E., Hopkins, J. R., Jones, C. E., Karunaharan, A., Lee, J., Mills, G., Misztal, P., Moller, S., Monks, P. S., and Whalley, L. K.: Simulating atmospheric composition over a South-East Asian tropical rainforest: performance of a chemistry box model, Atmos. Chem. Phys., 10, 279-298, doi:10.5194/acp-10-279-2010, 2010.

Pugh, T. A. M., MacKenzie, A. R., Langford, B., Nemitz, E., Misztal, P. K., and Hewitt, C. N.: The influence of small-scale variations in isoprene concentrations on atmospheric chemistry over a tropical rainforest, Atmos. Chem. Phys. Discuss., 10, 18197-18234, doi:10.5194/acpd-10-18197-2010, 2010.

Ren, X., Olson, J. R., Crawford, J. H., Brune, W. H., Mao, J., Long, R. B., Chen, Z., Chen, G., Avery, M. A., Sachse, G. W., Barrick, J. D., Diskin, G. S., Huey, L. G., Fried, A., Cohen, R. C., Heikes, B., Wennberg, P., Singh, H. B., Blake, D. R., Shetter, R. E.: $\mathrm{HO}_{\mathrm{x}}$ chemistry during INTEX-A 2004: Observation, model calculation, and comparison with previous studies, J. Geophys. Res., 113, D05310, doi:10.1029/2007JD009166, 2008.

Sander, R., Kerkweg, A., Jöckel, P., and Lelieveld, J.: Technical note: The new comprehensive atmospheric chemistry module MECCA, Atmos. Chem. Phys., 5, 445-450, doi:10.5194/acp-5-445-2005, 2005.

Sander, S. P., Finlayson-Pitts, B. J., Friedl, R. R., Golden, D. M., Huie, Kolb, C. E., R. E., Kurylo, M. J., Molina, M. J., Moortgat, G. K., Orkin, V. L., Ravishankara, A. R.: Chemical Kinetics and Photochemical Data for Use in Atmospheric Studies, Evalutation Number 14, JPL Publication 02-25, Jet Propulsion Laboratory, Pasadena, California, 2006.

Sander, S. P., Friedl, R. R., Golden, D. M., Kurylo, M. J., Moortgat, G. K., Wine, P. H., Ravishankara, A. R., Kolb, C. E., Molina, M. J., Finlayson-Pitts, B. J., Huie, R. E., and Orkin, V. L.: Chemical Kinetics and Photochemical Data for Use in Atmospheric Studies, Evalutation Number 15, JPL Publication 06-2, NASA Jet Propulsion Laboratory, Pasadena, California, 2006.

Saunders, S. M., Jenkin, M. E., Derwent, R. G., and Pilling, M. J.: World wide web site of a master chemical mechanism (MCM) for use in tropospheric chemistry models, Atmos. Environ., 31, p. 1249, http://www.chem.leeds.ac.uk/Atmospheric/MCM, 1997.

Saunders, S. M., Jenkin, M. E., Derwent, R. G., Pilling, M. J.: Protocol for the development of the Master Chemical Mechanism, MCM v3 (Part A): tropospheric degradation of non-aromatic volatile organic compounds, Atmos. Chem. Phys., 3, 161-180, 2003, http://www.atmos-chem-phys.net/3/161/2003/.

Saunois, M., Reeves, C. E., Mari, C. H., Murphy, J. G., Stewart, D. J., Mills, G. P., Oram, D. E., Purvis, R. M.: Factors controlling the distribution of ozone in the West African lower troposphere during the AMMA (African Monsoon
Multidisciplinary Analysis) wet season campaign, Atmos. Chem. Phys., 9, 6135-6155, 2009,

http://www.atmos-chem-phys.net/9/6135/2009/.

Schlosser, E., Brauers, T., Dorn, H.-P., Fuchs, H., Hseler, R., Hofzumahaus, A., Holland, F., Wahner, A., Kanaya, Y., Kajii, Y., Miyamoto, K., Nishida, S., Watanabe, K., Yoshino, A., Kubistin, D., Martinez, M., Rudolf, M., Harder, H., Berresheim, H., Elste, T., Plass-Dlmer, C., Stange, G., Schurath, U.: Technical Note: Formal blind intercomparison of $\mathrm{OH}$ measurements: results from the international campaign HOxComp, Atmos. Chem. Phys., 9, 7923-7948, doi:10.5194/acp-9-7923-2009, 2009.

Schmidt, U.: Molecular hydrogen in the atmosphere, Tellus, 26, 78-90, 1974.

Schmidt, U.: The latitudinal and vertical distribution of molecular hydrogen in the troposphere, J. Geophys. Res., 83, 941-946, 1978.

Sinha, V., Williams, J., Crowley, J. N., and Lelieveld, J.: The Comparative Reactivity Method - a new tool to measure total $\mathrm{OH}$ Reactivity in ambient air, Atmos. Chem. Phys., 8, 2213-2227, 2008 ,

http://www.atmos-chem-phys.net/8/2213/2008/.

Stavrakou, T., Peeters, J., and Müller, J.-F.: Improved global modelling of HOx recycling in isoprene oxidation: evaluation against the GABRIEL and INTEX-A aircraft campaign measurements, Atmos. Chem. Phys. Discuss., 10, 16551-16588, doi:10.5194/acpd-10-16551-2010, 2010.

Stickler, A., Fischer, H., Bozem, H., Gurk, C., Schiller, C., Martinez-Harder, M., Kubistin, D., Harder, H., Williams, J., Eerdekens, G., Yassaa, N., Ganzeveld, L., Sander, R., and Lelieveld, J.: Chemistry, transport and dry deposition of trace gases in the boundary layer over the tropical Atlantic Ocean and the Guyanas during the GABRIEL field campaign, Atmos. Chem. Phys., 7, 3933-3956, doi:10.5194/acp-7-3933-2007, 2007.

Stone, D., Evans, M. J., Commane, R., Ingham, T., Floquet, C. F. A., McQuaid, J. B., Brookes, D. M., Monks, P. S., Purvis, R., Hamilton, J. F., Hopkins, J., Lee, J., Lewis, A. C., Stewart, D., Murphy, J. G., Mills, G., Oram, D., Reeves, C. E., and Heard, D. E.: $\mathrm{HO}_{\mathrm{x}}$ observations over West Africa during AMMA: impact of isoprene and $\mathrm{NO}_{\mathrm{x}}$, Atmos. Chem. Phys., 10, 9415-9429, doi:10.5194/acp-10-9415-2010, 2010.

Tan., D., Faloona, I., Simpas, J. B., Brune, W., Shepson, P. B., Couch, T. L., Summer, A. L., Carroll, M. A., Thornberry, T., Apel, E., Riemer, D., and Stockwell, W.: $\mathrm{HO}_{\mathrm{x}}$ budgets in a deciduous forest: Results from the PROPHET summer 1998 campaign, J. Geophys. Res. 106, 24407-24427, 2001.

Taraborrelli, D., Lawrence, M. G., Butler, T. M., Sander, R., and Lelieveld, J.: Mainz Isoprene Mechanism 2 (MIM2): an isoprene oxidation mechanism for regional and global atmospheric modelling, Atmos. Chem. Phys., 9, 2751-2777, doi:10.5194/acp-9-2751-2009, 2009.

Thornton, J. A., Wooldridge, P. J., Cohen, R. C., Martinez, M., Harder, H., Brune, W. H., Williams, E. J., Roberts, J. M., Fehsenfeld, F. C., Hall, S. R., Shetter, R. E., Wert, B. P., and Fried, A.: Ozone production rates as a function of $\mathrm{NO}_{\mathrm{x}}$ abundances and $\mathrm{HO}_{\mathrm{x}}$ production rates in the Nashville urban plume, J. Geophys. Res., 107, 4146(D12), 4146, doi:10.1029/2001JD000932, 2002.

Vaghjiani, G. L. and Ravishankara, A. R.: Absorption cross sections 
of $\mathrm{CH}_{3} \mathrm{OOH}, \mathrm{H}_{2} \mathrm{O}_{2}$ and $\mathrm{D}_{2} \mathrm{O}_{2}$ vapors between $210 \mathrm{~nm}$ and $365 \mathrm{~nm}$ at $297 \mathrm{~K}$, J. Geophys. Res., 94, 3487-3492, 1989.

Wang, Y., Jacob, D. J., and Logan, J. A.: Global simulations of tropospheric $\mathrm{O}_{3}-\mathrm{NO}_{\mathrm{x}}$ - hydrocarbon chemistry. 3 Origin of tropospheric ozone effects of non-methane hydrocarbons, J. Geophys. Res., 103, 10757-10767, 1998.

Warneke, C., Holzinger, R., Hansel, A., Jordan, A., Lindinger, W., Pöschl, U., Williams, J., Hoor, P., Fischer, H., Crutzen, P. J., Scheeren, H. A., and Lelieveld, J.: Isoprene and Its Oxidation Products Methyl Vinyl Ketone, Methacrolein, and Isoprene Related Peroxides Measured Online over the Tropical Rain Forest of Suriname in March 1998, J. Atmos. Chem., 38, 167-185, 2001.

Whalley, L. K., Furneaux, K. L., Goddard, A., Lee, J. D., Mahajan, A., Oetjen, H., Read, K. A., Kaaden, N., Carpenter, L. J., Lewis, A. C., Plane, J. M. C., Saltzman, E. S., Wiedensohler, A., and Heard, D. E.: The chemistry of $\mathrm{OH}$ and $\mathrm{HO} 2$ radicals in the boundary layer over the tropical Atlantic Ocean, Atmos. Chem. Phys., 10, 1555-1576, doi:10.5194/acp-10-1555-2010, 2010.
Williams, J., Yassaa, N., Bartenbach, S., and Lelieveld, J.: Mirror image hydrocarbons from Tropical and Boreal forests, Atmos. Chem. Phys., 7, 973-980, doi:10.5194/acp-7-973-2007, 2007.

Zimmermann, P. R., Greenberg, J. P., and Westberg, C. E.: Measurements of atmospheric hydrocarbons and biogenic emission fluxes in the Amazon boundary layer, J. Geophys. Res., 93, 1407-1416, 1988. 